\title{
La teosofía en algunos periódicos salvadoreños y centroamericanos durante las décadas de 1930 y 1940
}

\section{Theosophy in some Salvadoran and Central American newspapers during the 1930s and 1940s}

\author{
Otto German Mejía Burgos \\ Universidad Centroamericana “José Simeón Cañas”, El Salvador \\ ottogmb7@,hotmail.com
}

Recepción: 20 de septiembre de 2017/Aceptación: 17 de noviembre de 2017

doi: https://doi.org/10.15517/rehmlac.v9i2.30538

Palabras clave

Jinarajadasa, teosofía, Iglesia católica, principios, positivismo.

Keywords

Jinarajadasa, theosophy, Catholic Church, principles, positivism.

Resumen

El presente artículo analiza la etimología del vocablo "teosofía", entendiendo este, en términos generales, como "sabiduría divina" o palabra mediante la cual se designa el conocimiento básico y común que existe entre las diversas religiones positivas tanto occidentales como orientales. Muestra también como dicho conocimiento se conjugó a su vez con los distintos sistemas filosóficos conocidos y la ciencia convencional para dar como resultado una especie de postura ecléctica la cual se opondría al positivismo lógico predominante. Además, desde la particular óptica del teósofo indio Jinarajadasa, hace un análisis pormenorizado de los principios teosóficos fundamentales los cuales se remontarían desde la más remota antigüedad hasta llegar hasta nuestros días.

Abstract

This research analyzes the meaning of the word "theosophy" understanding this, in general terms, like a "divine knowledge", a term used to compile the basic and common knowledge in differing positive religions from within the West and the East. This also presents the way in which the mentioned doctrine was a blend of different famous philosophical systems and conventional science thus creating a kind of eclectic posture which opposes the prevailing logical positivism. Also, since of the perspective of the theosophist Jinarajadasa made a detailed analysis of the fundamental theosophical principles, which comes from the remote antiquity until the present.

\section{Introducción}

Durante las décadas de 1930 y 1940 la teosofía tuvo un enorme impacto en toda la región centroamericana siendo uno de sus principales focos de difusión El Salvador. Este fenómeno no sería para nada casual, ya que en ese momento se encontraría en la presidencia de la República el General Maximiliano Hernández Martínez (1931-1944), famoso por ser reconocido miembro de las logias teosóficas y masónicas salvadoreñas. Evidentemente, esta investigación, desde un punto de vista académico constituye un trabajo pionero ya que pareciera ser que en el país más pequeño del continente ha habido 
una "minusvaloración", un "ocultamiento" o al menos una "desidia" a la hora de abordar tan escurridizo tema salvo pequeñas excepciones. Esta circunstancia, precisamente es la que ha impedido valorar de manera adecuada la enorme importancia que dicha doctrina tuvo en la configuración de los distintos modelos de Nación que se venían perfilando desde principios del siglo XX en todo el istmo.

Ahora bien, es en oposición a esta forma de descalificación a priori que el presente artículo trata de hacer visible la teosofía. Se centra en el pensamiento de una figura mundial de dicho movimiento: Jinarajadasa, quien visitaría Centroamérica en dos ocasiones: 1929 y 1938. El ensayo hará hincapié en algunos aspectos generales como: ¿Quién fue Jinarajadasa? ¿Cuál fue su visión sobre la teosofía? y -a juicio de este- ¿Cuáles fueron los principios esenciales de la misma? También, al final, se incluirán un pequeño apartado crítico sobre dichos principios.

La tesis fundamental de la investigación consiste en que la teosofía abrió nuevos espacios de sociabilidad entre la intelectualidad de la región y que se opuso a corrientes que habían empezado a entrar en crisis tales como el positivismo, el racionalismo, el marxismo, el materialismo y el ultramontanismo. Desde este ángulo tratar de comprenderla se vuelve un ejercicio imprescindible ya que ni en la misma época donde tuvo una mayor extensión y ni aún ahora se termina de entender cabalmente. Esto conlleva también a analizar el papel que jugó como alternativa ante la decadencia del proceso modernizador occidental que había perdido su rumbo y que encontraría una nueva dirección a partir de la adopción de ciertas creencias que provenían de oriente, y que en Europa y América, apenas se comenzaban a conocer, pero que, incluso, fueron integradas a ciertos postulados científicos muy respetados como la teoría del todo de Albert Einstein.

Habría que tomar en cuenta que en el período a analizar había mucha confusión en cuanto a qué era teosofía, por lo que predominaban las malas interpretaciones, los prejuicios y los ataques. Volver más diáfano y asimilable para los advenedizos lo que en un principio comenzó siendo una doctrina para "iniciados" fue la tarea que se impusieron muchos medios escritos de ese entonces, lo cual sería reforzado con la visita de emisarios de talla internacional como Jinarajadasa.

En el transcurso de este esbozo también se expondrán las fricciones que se dieron entre teosofía y positivismo, pero sin perder de vista que, al final, terminaron en una especie de conciliación o postura híbrida al menos de parte de la teosofía y de algunos positivistas de amplio criterio que se dejaron llevar por el anhelo de renovación. Respecto al racionalismo surge una vertiente teosófica mística dada al dogma, a lo increíble, al espiritismo y a los nuevos métodos pedagógicos como la intuición que trataban de irrumpir en un ambiente que se encontraba asfixiado por el intelectualismo. En cuanto al marxismo se refiere hubo la necesidad de implementar un reformismo social pacifista y estructural, que vendría a sustituir la revolución violenta, sobre todo en el caso de El Salvador después de los eventos sangrientos de 1932 que dejarían como saldo miles de muertos.

Ahora bien, uno de los planteamientos que aquí se hace es que la teosofía se opondría al marxismo, primero en cuanto a su ateísmo ontológico a través de la idea de un Dios Absoluto y espiritual, el cual desde el punto de vista científico sería interpretado como la "energía primera" que le dio origen a todo lo existente, luego a través del rechazo a la concepción de la muerte como fin de todo proyecto individual, a través del proceso de reencarnación en donde el alma sobreviviría y trascendería el mundo físico-temporal. 
Paralelamente se mostrará como por un lado la teosofía trató de armonizarse con las enseñanzas católicas a manera de un cristianismo esotérico y por el otro, como el catolicismo institucional y conservador se desvinculó de ella condenándola de forma categórica.

Es importante señalar que la teosofía llevó a la proliferación de una serie de sociedades en toda la zona perteneciendo a ellas principalmente miembros de las élites políticas, intelectuales, científicas, literarias y económicas, es decir, que la teosofía no fue algo que tuviera difusión en un primer momento dentro de los estratos sociales bajos, más sin embargo como lo demostrará este trabajo hubo un intento bien dirigido de aproximarla a las masas con el apoyo del Estado en el caso de El Salvador. En este punto habría que advertir que Rodríguez-Dobles establece que Hernández Martínez había desempeñado diversos puestos en la directiva de la logia Aletheia a finales de la década de los veinte y que, incluso, el 20 de febrero de 1931 la Sociedad Teosófica de Costa Rica le envió una carta de felicitación por haber sido electo vicepresidente de la República ${ }^{1}$ en su fórmula ganadora con Arturo Araujo (presidente).

Se aclara además que para el análisis panorámico se han utilizado conceptos que aparecieron después del deceso de Alberto Masferrer quien había venido fungiendo como el primer gran referente junto a Salarrué de dicho proyecto de Nación en El Salvador durante la década de 1920 y que durante la siguiente y mitad de la de 1940 tendría su continuidad de la mano de Hernández Martínez. Las fuentes consultadas fueron principalmente el Diario Oficial Suplemento La Republica y el Diario Nuevo, periódicos oficialistas que circularon durante la presidencia del referido militar aunque también se hizo revisión de otros como el Cronos de Guatemala o La Época de Honduras. En relación a los hallazgos, estos han tratado de ser presentados de la manera más sistemática posible, ya que hasta el momento lo que prevalece en la academia referente a la teosofía cuscatleca es la aridez historiográfica y la dispersión de las fuentes primarias.

Finalmente, habría que decir que desde el ámbito de la filosofía tradicional también han habido algunas posturas que se han planteado las mismas interrogantes que se formula la teosofía tal es el caso del escepticismo antiguo ${ }^{2}$ y del posmodernismo crítico, sobre todo de pensadores como Jean-Francois Lyotard quien proveyó de ciertas tesis fundamentales para criticar los grandes metarrelatos occidentales tales como: 1) la desconfianza en los macrosaberes comprendedores del todo, 2) la propuesta de formas débiles de racionalidad y 3) la llegada de una nueva ética del pluralismo y de la tolerancia ${ }^{3}$. Quizás estas corrientes son generalmente olvidadas o marginadas, porque obviamente implican un doloroso

\footnotetext{
${ }^{1}$ Esteban Rodríguez-Dobles, "Redes esotéricas en Centroamérica y Colombia (1904-1940). El caso de la sociedad teosófica", Melancolía $1, \quad$ (2016): http://revistamelancolia.com/index.php/melancolia/article/view/5/5

${ }^{2}$ Carlos Gutiérrez Rueda, "El escepticismo filosófico antiguo y el problema de la justificación epistémica", Revista Elementos: ciencia y cultura 10, no. 51 (2010): 44-45. El Escepticismo filosófico es la postura que niega que el ser humano pueda conocer. Se reconocen dos tipos de escepticismo, uno que acepta que se puede encontrar alguna respuesta (relativo) y otro que establece que no es posible encontrar una respuesta (absoluto). En la búsqueda de la verdad algunos filósofos han aceptado que la han encontrado, dogmáticos como: Aristóteles, Epicuro y los Estoicos, pero otros como Clitómaco y Carnéades consideran que no han encontrado la verdad, siguen buscando.

${ }^{3}$ Jean Francois Lyotard, "Qué es lo posmoderno", Zona Erógena 12 (1992): 2-10.
} 
proceso de desafección y relativización de las ideas culturalmente arraigadas en una tradición concreta y rígida como pueden ser las del catolicismo o las del marxismo, pero, sobre todo, porque constituyen un tipo de pensamiento reaccionario al dominante.

\section{Breve biografía de Jinarajadasa}

En primer lugar Curuppumullage Jinarajadasa (1875-1953) fue un teósofo originario de Ceylán perteneciente a la India inglesa, quien fue educado en las mejores universidades de la India, Inglaterra (Cambridge y Oxford), Italia (Pavia) y Francia ${ }^{4}$. Además, fue un escritor muy fértil cuyas obras se editaron en distintos países y en diversos idiomas ${ }^{5}$.

Es muy importante aclarar que el nombre verdadero de Jinarajadasa es el antes mencionado, pero - como es obvio advertir- por ser procedente de la India resultaba muy difícil de pronunciar en el idioma español; en base a esto se presume que en el medio social latinoamericano de la época se optó por hacer una castellanización libre, razón por lo cual solía designársele "Carlos", apelativo que obviamente era más asequible a estos países. En ese mismo afán, en el transcurso de este artículo, se adoptara esta última forma de conocerlo.

Dentro de su obra publicada hasta el periodo de sus incursiones por Centroamérica estaban: En su nombre y otros trabajos notables (1908); El Cristo y el Buddha (1910); Cristo y el lago (1913); Flores y jardines (1914); La teosofia y el pensamiento moderno en la herencia histórica y el arte y Lo que enseñamos (1915) Yo prometo, Como recordamos nuestras vidas pasadas y El mensaje del futuro (1917); La naturaleza del misticismo (1918); Teosofía práctica y La herencia de nuestros padres (1920); El arte y las emociones y Fe que es vida (1921); La unión del Oriente y del Occidente; Primeros rudimentos de la teosofía (traducido en cinco idiomas), Las primeras enseñanzas de los maestros y El reinado de ley (1923); La ley de Cristo; Fundamentos de teosofía (Obra premiada y traducida a ocho idiomas en Europa, Asia y América (1924); El libro de Oro de la S.T. (1925); El mediador y El arte como voluntad e idea (1928); El factor espiritual en la vida nacional; Ofrecimiento y La visión divina (1929); Apuntes de conferencias; La personalidad de H. P. Blavatsky (1930); La llama de la juventud y El maestro (Meditaciones en verso) (1931); Una biografía corta de Annie Besant; Agotamiento del karma y Ensayos teosóficos sobre el arte (1932); entre otros estudios publicados hasta $1934^{6}$.

Jinarajadasa comenzó su carrera como conferencista reconocido en 1904. También era considerado un pedagogo especializado en psicología y hablaba once idiomas dentro de los cuales, principalmente, dominaba: el antiguo sanscrito, el inglés, el francés, el italiano, el portugués y el castellano ${ }^{7}$.

\footnotetext{
${ }^{4}$ Emilio Narváez G., "El Doctor Jinarajadasa: breve semblanza de su personalidad", Diario Nuevo, 20 de septiembre de 1938,3 .

5 Narváez, "El Doctor Jinarajadasa", 3.

${ }^{6}$ Narváez, "El Doctor Jinarajadasa", 3.

${ }^{7}$ Narváez, "El Doctor Jinarajadasa", 3.
} 
Jinarajadasa ingresó en la Sociedad Teosófica Mundial con sede en la ciudad de Adyar, India, el 14 de marzo de 1893, dirigió su obra intelectual al cumplimiento de sus objetivos y llegó a convertirse en vicepresidente de la misma de 1921 a $1928^{8}$. Después de la muerte del teósofo y masón inglés George Arundale fue presidente desde 1945 hasta su muerte. Para la década de los treinta junto a Vivekananda ${ }^{9}$ y Ramacharaka formaba la trilogía sobre la cual descansaba la teosofía, que insistía en tener por líder y mesías a un Krishnamurti distanciado de la institución ${ }^{10}$.

El periodista Rigoberto García Parada ${ }^{11}$, ante su segunda visita a América sostuvo que Jinarajadasa - para los teósofos- constituía un verdadero "sophos", en el sentido de que dominaba distintas disciplinas como la ciencia, la moral, el misticismo, la historia, la política, la educación, entre otras. En esa ocasión, García Parada lo defendió de todos aquellos que lo acusaban de ser un difusor de meros dogmatismos de sectas corruptas, -el articulista creía más bien- que sus ideas estaban basadas en "leyes de la razón” y que dichas acusaciones eran "infundadas"12.

\footnotetext{
${ }^{8}$ La Época, "Mañana llegará a Tegucigalpa el filósofo C. Jinarajadasa”, 15 de octubre de 1938, 1. "A los catorce años bajo los auspicios de C. W. Ledbeater, salió para cursar en Inglaterra las materias de instrucción superior... regresó a su patria para aceptar el puesto de sub-director del Colegio Budista "Ananda," en Colombo pero dieciocho meses después presentó la dimisión de su cargo, por haber rehusado a renunciar a la ideología teosófica en su didáctica, según lo exigía la ortodoxia budista de la directiva del plantel. En 1912 paso nuevamente a Londres, esta vez para hacerse cargo de la instrucción secundaria de Krishnamurti".

${ }^{9}$ R. Arévalo Martínez, "Tres bellos libros de Román Rolland", La Prensa, $1^{\circ}$ de diciembre de 1934, 7. En la década de los treinta salieron a la luz tres volúmenes de una obra de Romain Rolland titulada Vivekananda, Ramakrishna y El Evangelio Universal en donde Rolland explica que Vivekananda declaró que las tres grandes formas de religión eran: el trabajo, la lealtad y la justicia, que constituían caminos para llegar a Dios; para el filósofo hindú todas las religiones buscan al mismo señor, todo el que marcha por alguna de ellas encuentra la salvación, según las enseñanzas "yoguis". Establece que todo es Dios y que cada uno debe olvidarse de sí mismo para servir a los demás argumentando que el único Dios que se debe adorar es el hombre que sufre y que se muere de hambre.

${ }^{10}$ Novedades, "Pronto llegará el filósofo Jinarajadasa", 21 de septiembre de 1938, 1.

${ }^{11}$ Rigoberto García P., "C. Jinarajadasa”, Diario Latino, 13 de septiembre de 1938, 3. "Jinarajadasa es artista. En sus obras, aún en las que aborda tópicos áridos, científicos se subliman los hechos, el amor se infiltra en las frases y campea estéticamente haciendo amable el pavoroso Anamké (...) por ser artista habla siempre de arte aún sin quererlo (...) Jinarajadasa estima que el ejercicio de cualquier arte es disciplina indiscutible en eficacia para dar expansión a las facultades latentes del ser humano".

${ }^{12}$ Rigoberto García P., “¿Quién es Jinarajadasa?”, Cronos, 12 de octubre de 1938, 2.
} 


\section{Imagen 1}

Artículo de prensa: ¿Quién es Jinarajadasa?

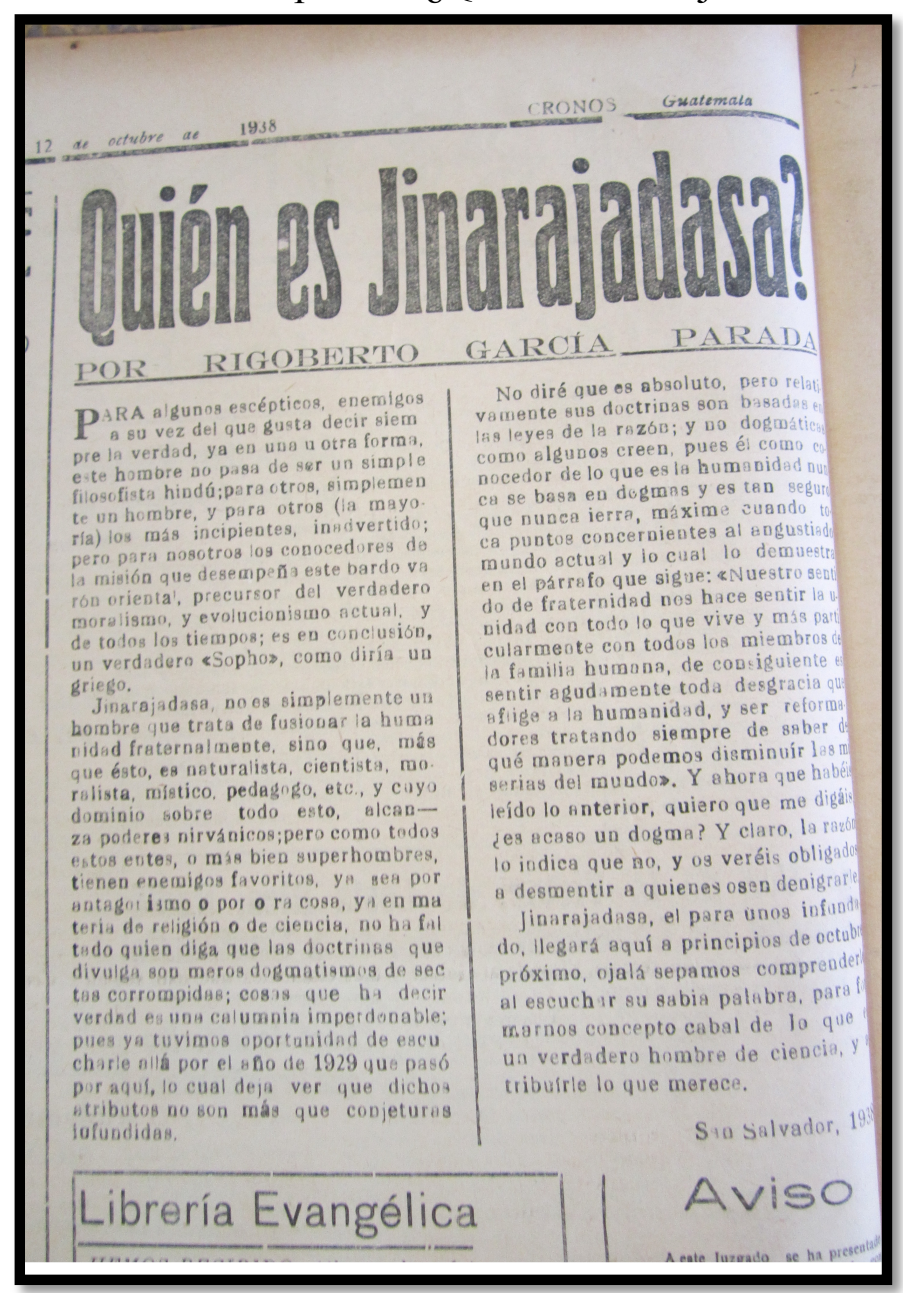

Fuente: Rigoberto García P., ¿¿Quién es Jinarajadasa?”, Cronos, 12 de octubre de 1938, 2.

\section{Qué es la teosofía, según Jinarajadasa}

Jinarajadasa expuso que la Sociedad Teosófica mundial, para el momento en el que dio las declaraciones, tenía un poco más de setenta años de existencia, pero que a pesar de ese poco tiempo, contaba con más de cincuenta secciones nacionales distribuidas en toda la India y más de 150,000 miembros diseminados en todo el mundo. Durante las décadas de los veinte y los treinta, según él, la teosofía tuvo un incremento considerable.

Jinarajadasa explica que la parte esotérica de toda enseñanza, sea esta religiosa, filosófica o científica ${ }^{13}$, ha sido reservada en todo tiempo, para quienes deseen adquirir el

\footnotetext{
${ }^{13}$ Esteban Cortijo Parralejo, "Vida y obra de Mario Roso de Luna, 1872-1931, abogado, científico y escritor", (Tesis de doctorado en filosofía, Universidad Complutense de Madrid, 1991), 184-185. Para Roso, el teósofo en todo tiempo a tratado de responder a las preguntas clásicas de la metafísica apoyado por la ciencia
} 
conocimiento directo de la divinidad ${ }^{14}$, como el místico y el filósofo (de sus propósitos) y el científico (de sus procedimientos). Esta enseñanza, según él, se conoció en Occidente en el Siglo III con el nombre de teosofía ${ }^{15}$ : "Históricamente la palabra "teosofía" denota un cuerpo de verdades o de hechos concernientes a la divinidad (religión), a la conciencia y a la evolución (filosofía) y a la constitución del Universo y del hombre (ciencia)"16.

En consonancia con esta visión, José Florentín Rosales Rodas definió el espiritismo centroamericano como "la doctrina filosófica, científica y moral, que basándose en una rica y variada fenomenología probaría la existencia del alma, del mundo espiritual y la inmortalidad del espíritu" "17. Según Luis A. Urbina el espiritismo no era una doctrina satánica o creencias provenientes de la imaginación supersticiosa de un grupo de personas ignorantes sino fenómenos paranormales auténticos, pero inexplicables aún para la ciencia oficial $^{18}$.

convencional. En su obra, religión, ciencia y filosofía constituyen una concepción integral del hombre y del mundo: ¿Quiénes somos?; ¿De dónde venimos?; ¿Adónde vamos?

${ }^{14}$ Diario Nuevo, "El Señor Presidente Martínez habló sobre la educación y la instrucción", 28 de octubre de 1943, 3. "La instrucción pertenece al dominio de la ciencia; la educación a la de la conciencia (...) al examinar las materias de discusión, conviene atender a su aspecto filosófico. La filosofía puede aplicarse por igual a las ciencias, el arte y la moralidad. Sin una filosofía humana la ciencia no conduce al bien ni a la justicia. Porque hay lo que podríamos llamar filosofía de las matemáticas como la de Pitágoras que penetró en la esencia de las cosas y dijo que Dios es el ser que crea y anima todas las formas. Dios es la vida. La Física conduce al materialismo y al espiritualismo, según se le estudie. Cuando comprendemos que toda materia se transforma en energía, vamos en camino de reconocer la causa única".

${ }^{15}$ Cronos, "Pronto nos visitara el Dr. Jinarajadasa", 15 de octubre de 1938, 3.

${ }^{16}$ Cronos, "Pronto nos visitara", 3.

${ }^{17}$ Marta Elena Casus Arzú, "El vitalismo teosófico como discurso alternativo de las élites intelectuales centroamericanas en la década de 1920 y 1930. Principales difusores: Alberto Masferrer, Carlos Wild Ospina y Porfirio Barba Jacob", REHMLAC 3, no. 1 (mayo-noviembre 2011): 89, https://revistas.ucr.ac.cr/index.php/rehmlac/article/view/6588/6279

${ }^{18}$ Luis A. Urbina, "El espiritismo", Diario Nuevo, 3 de agosto de 1938, 3. 
Imagen 2

Artículo de prensa: El espiritismo

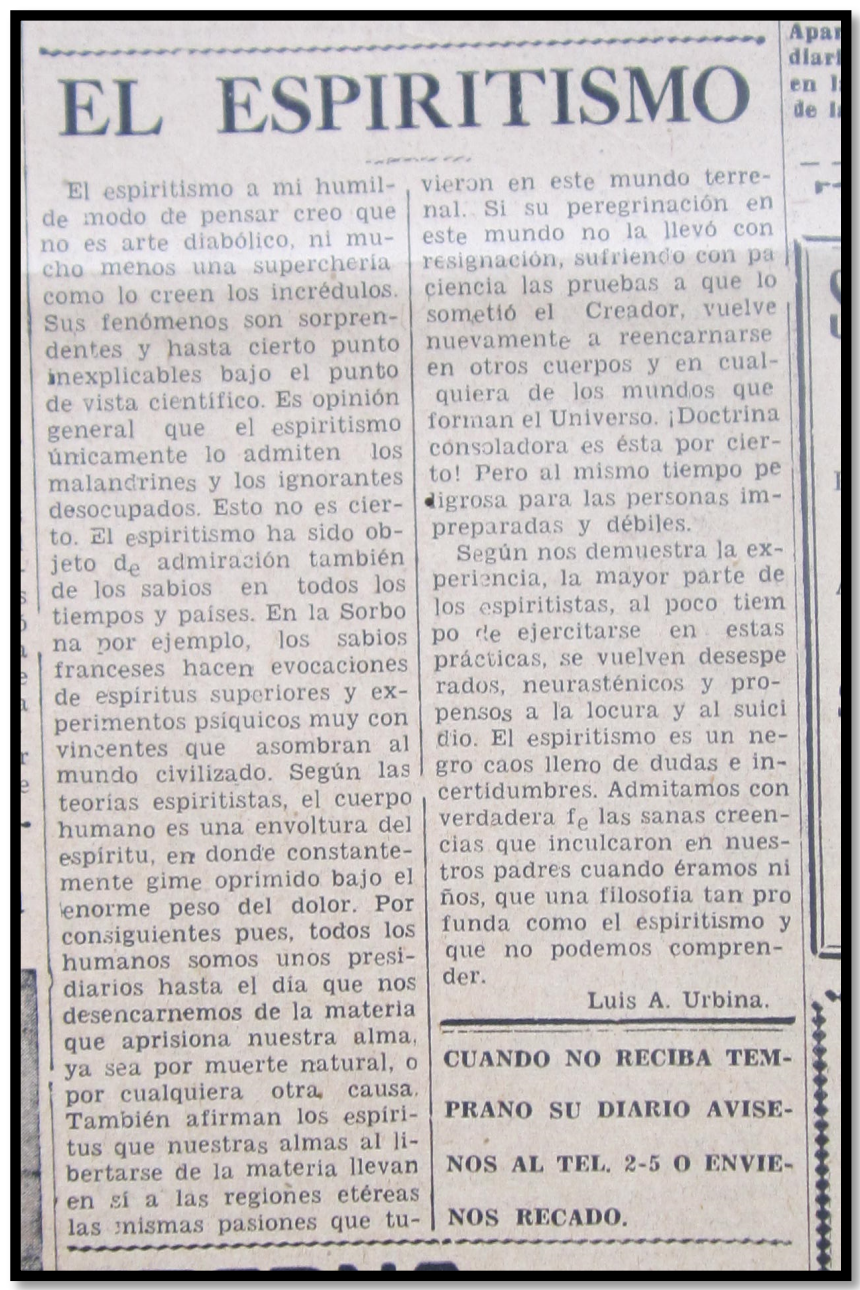

Fuente: Luis A. Urbina, "El espiritismo", Diario Nuevo, 3 de agosto, 1938, 3.

Ahora bien, Jinarajadasa también expresó que la teosofía era un conocimiento verdadero que intentaba ganar adeptos y difundir lo que él denominaba "el evangelio de la vida", en clara oposición a sus detractores que la calificaban de ser una doctrina falsa y vacía. El problema radical para aquellos que la profesaban, según el hindú, era que históricamente desde su fundación se había mal interpretado, por lo que había una gran intolerancia, que partía del desconocimiento, el fanatismo y la tergiversación de algunos sectores, pero principalmente de la Iglesia católica ${ }^{19}$.

Chester Urbina señala, por ejemplo, que la Iglesia católica en Costa Rica se mostró muy reacia a admitir otras formas de religiosidad atacando de manera frontal a la teosofía. Esta se opuso a la enseñanza de la teosofía en las escuelas, ya que al muy estilo del medioevo la Iglesia se consideraba dueña de la verdad. En este sentido tanto la teosofía como la masonería se opondrían a esa razón inexpugnable propia de la alta jerarquía

\footnotetext{
${ }^{19}$ Carlos Jinarajadasa, "Que es la teosofía”, Diario Nuevo, 26 de octubre de 1938, 5.
} 
verticalista y es por eso que es entendible que la Iglesia haya reaccionado con tanta virulencia en contra de ellas, incluso a través de la formación de sociedades y periódicos de defensa de la fe católica ${ }^{20}$.

La justificación de los ataques era que la teosofía alejaba a los jóvenes de la sana doctrina y es por eso que muchos sacerdotes tomaron la determinación de desprestigiar a los líderes más visibles de dicha sociedad. Por otro lado, los teósofos se defendieron haciendo llamados a la "tolerancia" y exhortando a sus seguidores a no caer en las provocaciones de estos sectores ultraconservadores aunque también habría que decir que la difusión de la teosofía se dio dentro de un contexto de duras críticas al catolicismo por su inoperancia para oponerse al materialismo marxista y positivista que estaba acabando con la idea de Dios y también por su incompetencia para promover la igualdad entre la mujer y el hombre tanto en el campo social como en el político ${ }^{21}$ y de ahí que la teosofía haya desarrollado otra fuerte vertiente feminista.

Este enfrentamiento entre católicos y teósofos también puede observarse claramente en las palabras del teósofo Remy Roger ante la segunda visita de Jinarajadasa a Honduras, quien expresó que en los medios locales se publicaron una serie de afirmaciones ridículas, que la hacían pasar por hechicería o brujería $^{22}$, hecho, que evidenciaba la conflictividad que existía entre dos cosmovisiones que, en ciertos aspectos, como se verá más adelante trataron de conciliarse, al menos de parte de la Sociedad Teosófica.

Jinarajadasa dentro de este mismo análisis aseguró que uno de los errores más comunes al querer conocer la teosofía, es pensar que se trata de una nueva religión, lo cual negó rotundamente. Esta primera observación es muy importante, ya que la teosofía no funciona como el catolicismo o el protestantismo cristianos de una forma institucional, jerárquica, estructurada y con autoridades establecidas sino que más bien funciona de forma similar a las logias masónicas y se aproxima mucho a lo que podría denominarse un "espiritualismo laico", aunque Jinarajadasa aclaró que la teosofía sí toma ciertos elementos de las distintas religiones tradicionales:

La teosofía no es una nueva religión, contiene verdades que se encuentran en todas las religiones, pero no es un nuevo culto, con nuevo credo, nuevos sacerdotes y nueva promesa de salvación. Es más bien, una filosofía científica de la vida, basada en el descubrimiento de hechos relativos a la vida misma ${ }^{23}$.

Desde esta óptica, la teosofía busca legitimarse a través de la ciencia, es decir, intencionalmente intenta abrogarse un poco del prestigio que sabe que gozan las ciencias fácticas-verificables, pero sin reducirse a solo ser ciencia; da la impresión que los teósofos aunque surgieron en contraposición al positivismo, no podían ponerse de espaldas a la ciencia, ya que podían ser catalogados como "dogmáticos" o "ignorantes" y a pesar de que

\footnotetext{
${ }^{20}$ Chester Urbina Gaitán, "Iglesia, Estado y control mental en Costa Rica: el caso de la prohibición de la enseñanza de la teosofía en el Colegio Superior de Señoritas, 1922”, Revista de Ciencias Sociales 150 (2015): 59.

${ }^{21}$ Urbina Gaitán, "Iglesia, Estado y control mental en Costa Rica”, 60.

${ }^{22}$ Remy Roger, "Concepto errado que de la teosofía tienen algunos", El Cronista, 31 de octubre de $1938,7$.

${ }^{23}$ Jinarajadasa, "Que es la teosofía”, 5.
} 
buscaron fundamentar sus dogmas en algunas teorías científicas, esto no impidió que dichos improperios fueran lanzados en su contra de todas maneras:

En todos los órdenes, los progresos de la civilización deben mucho a la ciencia moderna. La ciencia moderna es grande porque observa primero hechos, sin teoría preconcebida, después del estudio de los hechos deduce ciertas conclusiones generales. Nosotros hemos encontrado que el método científico nos permite descubrir en lo que concierne a la naturaleza del hombre, verdades que las teologías no nos habían revelado ${ }^{24}$.

Jinarajadasa, inclusive, llega a establecer que existe un mismo estatus epistemológico entre ciencia y teosofía, en razón de que la primera ha realizado los más grandes descubrimientos hechos por los sabios modernos y la segunda, constituye el enunciado de saberes tanto modernos como de civilizaciones antiguas ${ }^{25}$. Esta postura podría ser un poco desproporcionada en el afán de querer legitimar la teosofía, ya que de haber tenido el mismo rango que la ciencia, no hubiese perdido toda la relevancia y la aceptación que tuvo en esa época, pero si refleja al menos, el papel decisivo que se le quiso adjudicar frente a la visión reduccionista del positivismo que pretendía suprimir de una vez para siempre la sabiduría ancestral juzgada como la infancia de la humanidad la cual tenía que ser superada.

\section{Imagen 3}

Artículo de prensa de Jinarajadasa, ¿Qué es la teosofía?

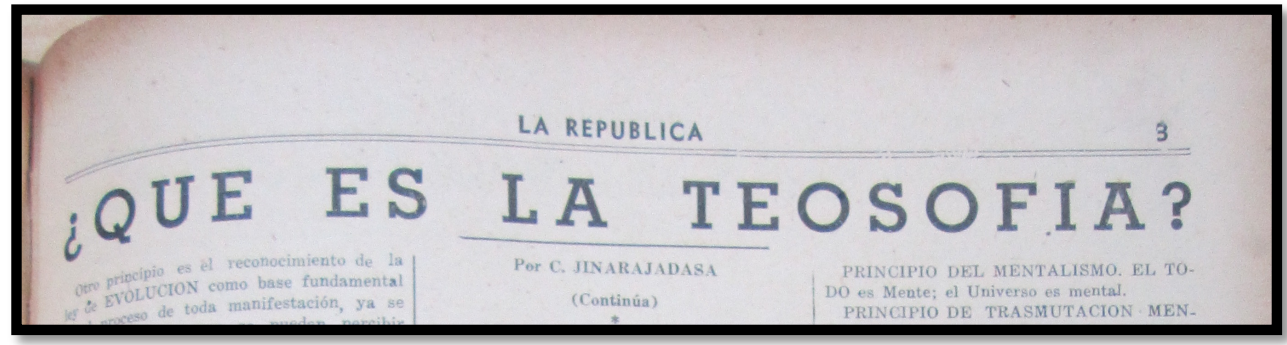

Jinarajadasa, "¿Qué es la teosofía?", Diario Oficial, Suplemento La República, 26 de agosto de 1942, 3.

Según Horacio González, un ejemplo de esto fue el médico y filósofo argentino José Ingenieros, quien cuestionaba el monopolio que de la verdad habían hecho los "sabios" de la ciencia oficial. Ingenieros, según González, defendía la posición de que el ocultismo y la teosofía se introdujeran como estudios de indiscutible veracidad dentro del campo científico $^{26}$. Habría que ser cauteloso con esta afirmación ya que, en realidad, Ingenieros jamás dejó de ser un pensador positivista en el sentido estricto de la palabra e incluso fue muy crítico con los movimientos místicos y espiritualistas de la época, pero habría que decir también que en su obra Las direcciones filosóficas de la cultura argentina sí

\footnotetext{
${ }^{24}$ Jinarajadasa, "Que es la teosofía", 5.

25 Jinarajadasa, "Que es la teosofía”, 5.

${ }^{26}$ Horacio González, Historia crítica de la sociología argentina: los raros, los clásicos, los científicos, los discrepantes (Buenos Aires: Ediciones Colihue, S.R.L, 2000), 17.
} 
reconoció el impacto que la teosofía tuvo en el ámbito de la filosofía de ese país aún por encima de autores de la academia tradicional tales como Kant o Hegel:

El contradictorio sistema de Kant y el panteísmo ideologista de Hegel no tuvieron aquí discípulos en el siglo XIX. No alcanzaron hondo arraigo los eclécticos franceses, ensayados en algún momento como una transición cómoda entre la escolástica y el naturalismo científico, ni tuvo partidarios conocidos el neocriticismo francés, no obstante ser, como el eclecticismo, una fórmula transitiva entre lo viejo que ya no se cree y lo nuevo que no puede creerse todavía. Los eclécticos del resurgimiento italiano fueron absolutamente desconocidos, lo mismo que los krausistas españoles. En nuestro ambiente pedagógico encontró acogida entusiasta el positivismo de Augusto Comte. Alguna difusión han tenido en el país las corrientes sociológicas que parten de Marx y Bakounine, el espiritismo, la teología protestante y los estudios teosóficos ${ }^{27}$.

Ahora bien, autores que creían que se debían conciliar ciencias objetivas con espiritualismo eran: William Crookes en Inglaterra, Lombroso en Italia y Carlos Richet en Francia, este último quien tenía un doctorado en medicina (1869) y otro en ciencias (1878). La académica Soledad Quereilhac, incluso, asevera que dentro de los miembros de la Sociedad Teosófica Argentina, figuraron prominentes positivistas como el ingeniero Rodolfo Moreno y la médica Margarita Práxedes Muñoz directora de la revista La filosofía positiva $^{28}$.

El académico español Jordi Pomés Vives asegura que el mismo inventor norteamericano Thomas Edison fundó junto a Blavatsky la Sociedad Teosófica. Einstein también simpatizó con la teosofía y se la recomendó a su colega alemán Heisenberg. Otros científicos que simpatizaron con dicho movimiento fueron el astrónomo francés NicolásCamile Flammarion, los físicos norteamericanos Robert Millikan y Robert Oppenheimer y el naturalista inglés Alfred Russel Wallace. Algunos filósofos importantes sobre quienes también influyó fueron el estadounidense William James, más conocido por su obra Pragmatismo, y el alemán Franz Hartmann, cuya obra es esencialmente teosófica ${ }^{29}$. José Ramón Ayllón, en su libro En torno al hombre: introducción a la filosofía, explica que este fenómeno pudo haberse dado porque:

...la metafísica se ocupa de los problemas que aparecen en el límite de la investigación física. A lo largo de la historia, ambas tareas han sido frecuentemente

\footnotetext{
${ }^{27}$ José Ingenieros, Las direcciones filosóficas de la cultura argentina, (Buenos Aires: Eudeba editorial Universitaria, 1963), 90-91.

${ }^{28}$ Soledad Quereilhac, "Sociedades espiritualistas en el pasaje de siglos: entre el cenáculo y las promesas de una ciencia futura, (1880-1910)", Revista de historia intelectual: Prismas 16 (2012): 185.

${ }^{29}$ Jordi Pomés Vives, "Dialogo Oriente-Occidente en la España de finales del siglo XIX. El primer teosofismo español (1888-1906) un movimiento religioso heterodoxo bien integrado en los movimientos sociales de la época", Orientats 4 (2006): 58. Dentro de las obras de Hartman se encuentran: Magia blanca y magia negra (1886), Una aventura en la mansión de los adeptos rosacruces (1887), Los elementales (1887), Símbolos secretos rosacruces (1888), Principios de geometría astrológica (1889), En el pronaos del templo de la sabiduría (1890), Ciencia oculta en la medicina (1893) y Entre los gnomos (1895).
} 
unidas en las mismas personas, aunque con diverso éxito (piénsese en Pitágoras, Tales, Aristóteles, Alberto Magno, Descartes, Leibniz, Pascal, Newton, Einstein...). La razón es ésta: los grandes hombres de ciencia, deseando encontrar más allá de la ciencia las respuestas a los últimos porqués, continuaron la búsqueda de la verdad por el camino de la filosofía, pues "todo verdadero investigador - dice Einstein- es una especie de metafísico oculto, por muy positivista que se crea"30.

Aun en el mundo occidental actual es difícil asimilar esta conjunción o hibridación entre filosofía, religión y ciencia, porque son campos que comúnmente aparecen de forma separada e, inclusive, en ocasiones -para explicar determinados fenómenos- están en franca oposición, prevaleciendo de manera contundente la ciencia que se impone a los dogmas religiosos y a las metafísicas especulativas de la filosofía. Obviamente esta última aseveración es hecha desde el positivismo más duro y puro que intentaba huir del nominalismo de la escolástica. Es así como el positivismo predominó en la mayoría de países latinoamericanos desde finales del siglo XIX y en base a él se empezaron a configurar distintos proyectos de nación, que funcionarían bajo una premisa primordial: "el afán de progreso", tal y como lo afirma Gerardo Mora Burgos en su libro La filosofía en América Central en el siglo XX cuando dice:

Hilario Vallejo sostiene que "los hispanoamericanos pensaron utópicamente que con el positivismo su mundo estaría arreglado. Los mexicanos creyeron superar la larga anarquía que los aquejaba. Los argentinos lo consideraron como un remedio eficaz para curar las mentes absolutistas y tiránicas que padecían. Los chilenos, por su parte, se adhirieron al positivismo con la finalidad de utilizarlo como medio para implementar los ideales del liberalismo. En el Uruguay se lo consideró como la doctrina moral capaz de neutralizar la larga era de cuartelazos y corrupciones. Perú y Bolivia lo tomaron como consolación de su fracaso con Chile. Los cubanos lo asumieron como la bandera de su independencia de España". Desde esta perspectiva, el positivismo en Hispanoamérica surge como una panacea no sólo en el plano filosófico, sino también social, político y pedagógico, aunque también adquiere sus propios rasgos en cada país. Leopoldo Zea afirma que se puede hablar de un positivismo hispanoamericano; pero también, con el mismo derecho, de un positivismo mexicano, argentino, uruguayo, chileno, peruano, boliviano o cubano ${ }^{31}$.

La teosofía, entonces, surge en contraposición a esta gran tendencia positivista sin hacer discriminaciones o exclusiones hacia la religión o la filosofía, mediante el enunciado de que la "inteligencia humana" es solo una y que el fin último de la misma, es descubrir la "verdad" sin prestar atención a divisiones cognoscitivas. Además, Jinarajadasa establece que la ciencia en muchos aspectos ha sido impulsada por la teología y la filosofía y que el desarrollo de la ciencia, escasamente ha tenido lugar hace unos cuantos siglos atrás, pero al

\footnotetext{
${ }^{30}$ José Ramón Ayllón, En torno al hombre: introducción a la filosofía (Madrid: Ediciones Rialp, 2001$), 18$.

${ }^{31}$ Gerardo Mora-Burgos, La filosofía en la América Central en el siglo XX (Madrid: Editorial Cátedra, 2009), 4.
} 
mismo tiempo, expresa que la ciencia es indispensable para ir rectificando los distintos errores del pasado ${ }^{32}$.

Jinarajadasa pone como ejemplos los descubrimientos realizados en esa época por la biología y la zoología, que demostraban que la civilización humana era mucho más antigua de lo que afirmaba la historia. Por otra parte, expresa que sociedades antiguas como las de Egipto, Babilonia y la Atlántida, tuvieron sabios tan versados en el arte de la observación como los científicos contemporáneos y que también realizaron descubrimientos verdaderamente relevantes para la humanidad en campos como la astrología y las matemáticas. Descubrimientos que en muchos sentidos estaban vinculados a sus creencias filosóficas y teológicas ${ }^{33}$.

En definitiva, el concepto que Jinarajadasa ofrece de teosofía es el siguiente: "Es una exposición de hechos referentes al hombre, a la naturaleza y a Dios, descubiertos por los sabios de las generaciones pasadas y presentes por medio del método científico"34. De esta definición se derivan algunas interrogantes como: ¿Quiénes eran esos sabios antiguos? y ¿quiénes son en la actualidad? Los primeros, según el hindú, fueron aquellos que los teósofos llamaban "maestros de la sabiduría"; calificativo con el que designan a hombres con un tipo más elevado de conciencia cuyo intelecto ha sido desarrollado más a plenitud. Son hombres con emociones purificadas en su grado máximo y representan el más alto escaño en la evolución del espíritu humano, es decir, son seres más perfeccionados en todas sus dimensiones, por lo que se distinguen del resto de la humanidad. Estos hombres superiores regresan de tiempo en tiempo en otro cuerpo físico, mediante el proceso de la re-encarnación con el objetivo de proseguir con sus enseñanzas: "Los maestros de sabiduría son perfectos santos por su naturaleza sensible; más por sus facultades intelectuales, son sabios profundos. Esto quiere decir que han adquirido su saber escrutando los misterios del Universo, con ayuda de todas sus facultades"35.

Según Jinarajadasa, la teosofía ha existido desde los inicios de la humanidad en forma de "especulaciones" que los pueblos antiguos hicieron por medio de su conciencia superior, encontrándose su rastro en Los Upánishads, Los Puranas y en Las seis dársanas o sistemas de filosofía hindúes, en el taoísmo y en los clásicos de la pureza de los chinos, en El libro de los muertos de los egipcios, en el Gathás y otras escrituras persas, en La Cábala y El Talmud de los hebreos, en Pitágoras y Platón y en las escrituras cristianas de los primitivos ${ }^{36}$.

También establece que fue Ammonio de Sacca y los neoplatónicos quienes fundaron el sistema filosófico conocido como "Teosofismo Ecléctico", el cual era un sistema ético que conllevaba una fe fundamentada en tres principios universales: 1) la creencia en un Dios, esencia infinita o raíz de la physis (naturaleza), 2) la creencia en la

\footnotetext{
32 Jinarajadasa, "Qué es la teosofía", 5.

33 Jinarajadasa, "Qué es la teosofía", 5.

${ }^{34}$ Cronos, "Pronto nos visitará el Dr. Jinarajadasa: algunas de sus ideas acerca de la teosofía", 15 de octubre de 1938, 3. "La teosofía difiere con la ciencia moderna en que, bajo la denominación de ciencia, incluye la investigación en los mundos supra-físicos pero sus métodos son iguales; investigación mediante la observación de los fenómenos objetivos; razonamiento a base de dicha observación y formulación de hipótesis para descubrir las leyes naturales".

35 Jinarajadasa, "Qué es la teosofía", 5.

${ }^{36}$ Jinarajadasa, “QQué es la teosofía?”, Diario Oficial, Suplemento La República, 25 de agosto de 1942, 3.
} 
inmortalidad del hombre cuya esencia es idéntica a la del alma universal y 3) la teúrgia u obra divina. Para el hindú, los neoplatónicos como Plotino y Porfirio fueron los primeros en estudiar de forma sistemática la teosofía e, inclusive, afirma que el mismo Jámblico ${ }^{37}$ escribió una obra titulada Misteriis ${ }^{38}$.

En su opinión, la teosofía también se encontraría en los padres gnósticos de la Iglesia como Valentino, Basílides, Orígenes, Clemente y Athenágoras, en los Teugistas, en los doctores del Islam y con los estudiantes rosacruces de la alquimia como Paracelso y Bruno y otros que añade José Luis Abellán como Cornelio Agripa y Jean Baptista van Helmont, quienes fueron seguidos por Jacob Böhme y Swedenborg ${ }^{39}$. Finalmente, Jinarajadasa cree que puede descubrirse en el judaísmo, sobre todo, a través de los rabinos ilustrados de las sinagogas ${ }^{40}$. Desde su perspectiva, su renacimiento se debía a la Sociedad Teosófica mundial fundada en Nueva York en 1875 por Helena Petrovna Blatvasky y Henry Steel Olcott ${ }^{41}$ :

La teosofía como sistema para desarrollar este conjunto de enseñanzas principió a usarse, según Diógenes Laercio, en los primeros tiempos de la dinastía Ptolomaica. Este sistema es de origen copto y el primero que la uso para designar la Sabiduría Divina fue el sacerdote egipcio llamado Post-Amun (dios de la sabiduría). Esta sabiduría nos vino a través de los filósofos alejandrinos llamados "Filaleteos o amantes de la verdad ${ }^{42}$.

Xavier Zubiri por su parte, sostiene que tanto en los primeros filósofos griegos como en los antiguos himnos védicos, Brahmanas y Upanishads más antiguos está presente la idea de la totalidad y de la nada. El filósofo español explica que estas escrituras sagradas entienden el Universo como lo Absoluto (Brahman) y que el indio se dirige hacia este Universo, ya sea para evadirlo o para sumergirse en él, como la raíz de su divinidad y que esto es lo que históricamente le ha provisto de sentido a su existencia ${ }^{43}$ :

\footnotetext{
${ }^{37}$ Giovanni Reale y Dario Antíseri, Historia de la filosofía, tomo I: filosofía pagana antigua, (Bogotá: Editorial San Pablo, 2007), 566. Jámblico fue mucho más allá pues desdobló el Uno en un primero y un segundo Uno. Además, sub-dividió la hipóstasis plotoniana del espíritu a un plano de lo intangible subdividido en una "tríada" y un plano intelectual, diferenciado de manera "tríadica" y en una de esas tríadas identificó la hipóstasis (sustancia) del alma.

38 Jinarajadasa, “¿Qué es la teosofía?”, 3.

${ }^{39}$ José Luis Abellán, Historia crítica del pensamiento español: la crisis contemporánea, 1875-1936, Tomo VII (Madrid: Editorial Espasa-Calpe S.A., 1988), 430.

${ }^{40}$ Jinarajadasa, “¿Qué es la teosofía?”, 3.

${ }^{41}$ Cronos, "Pronto nos visitará el Dr. Jinarajadasa: algunas de sus ideas acerca de la teosofía", 15 de octubre de 1938,3 .

42 Jinarajadasa, “¿Qué es la teosofía?”, 3.

${ }^{43}$ Xavier Zubiri, Naturaleza, historia y Dios (Madrid: Alianza Editorial S.A., Fundación Xavier Zubiri, 2004), 207.
} 
Es la identidad del Atman y del Brahman. El hombre se siente parte de un todo absoluto, y a él revierte. La sabiduría del Veda tiene, ante todo, un carácter operativo. Es verdad que en algún día pretenderá pasar por etapas que pueden parecerse a un conocimiento casi especulativo. Pero este conocimiento es siempre una acción cognoscitiva, orientada hacia el Absoluto, es una comunión con él. En lugar de fisiología jónica, tenemos la teosofía y la teúrgia brahmánicas ${ }^{44}$.

Esteban Cortijo Parralejo en su tesis doctoral titulada "Vida y obra del Dr. Mario Roso de Luna, (1872-1931), científico, abogado y escritor" manifiesta que los objetivos con los que nació la Sociedad Teosófica fueron tres: 1) fomentar un núcleo de fraternidad universal, sin distinciones de raza, color, credo o sexo; 2) fomentar el estudio de las escrituras sagradas y ciencias del mundo y reivindicar la importancia de la antigua literatura asiática y principalmente de las filosofías brahmánica, budista y zoroastriana y 3) Investigar los misterios ocultos de la naturaleza bajo todos los aspectos posibles y los poderes psíquicos y espirituales latentes en el hombre ${ }^{45}$.

Desde este ángulo, lo que ha hecho la teosofía a través de la historia humana, según Jinarajadasa, es tomar todas aquellas consideradas como "verdades eternas" que se encuentran en todas las religiones para ir construyendo así una filosofía propia, ya que los teósofos consideran que estas no pueden estimarse como patrimonio exclusivo de cada una de ellas ${ }^{46}$.

Jinarajadasa, incluso, establece que el apóstol Santiago se refirió a la teosofía cuando hizo una distinción entre "sabiduría humana, demoníaca o de abajo" y la "sabiduría de arriba" o la que viene del "anciano de los días"47. Por otra parte, sostiene que la teosofía es un cuerpo de enseñanzas que ha permanecido oculto entre los diferentes templos e instituciones iniciáticas ${ }^{48}$, que actualmente conocemos como logias o sociedades secretas. Estas verdades también habrían tenido una gran trascendencia en las religiones tradicionales a través de los "misterios" que revelan, pero que normalmente no son lo suficientemente comprendidos 49 .

\footnotetext{
${ }^{44}$ Zubiri, Naturaleza, historia y Dios, 207.

${ }^{45}$ Cortijo Parralejo, "Vida y obra del Dr. Mario Roso de Luna", 139-140.

${ }^{46}$ Cronos, "Pronto nos visitará el Dr. Jinarajadasa: algunas de sus ideas acerca de la teosofía", 18 de octubre de 1938, 3. "Todo lo más espiritualmente refinado, lo más sublime de las Escrituras Sagradas de todo el mundo; lo más ennoblecedor e inspirador en los escritos de filósofos y moralistas, forma la ética de la teosofía: el teósofo se esfuerza por vivir de acuerdo con el espíritu de Cristo y Buda más bien que a código penal o social alguno".

${ }^{47}$ Cronos, "Pronto nos visitará", 3.

${ }^{48}$ G. Oliva N., "Éxtasis e introspección", Diario de Oriente, 23 de marzo de 1938, 3. Es interesante este ritualismo iniciático de la teosofía, en donde el candidato a convertirse en teósofo debe leer algunas obras que le proporcionaran un conocimiento básico de las doctrinas esotéricas dentro de las cuales están: La doctrina secreta, La voz del silencio e Isis sin Velo de Madame Blatvasky; El Bhagavad Gita, El sendero de la iniciación, Hacia el templo, Leyes de la vida superior, Los tres senderos de la perfección y Doctrina del corazón de Annie Besant; Clarividencia y Clauriaudiencia de Leadbeter, Filosofía yoga de Vivekananda; Magia blanca y magia negra de Hartman; Flores y jardines de Jinarajadasa y A los pies del Maestro de Krishnamurti.

49 Jinarajadasa, “¿Qué es la teosofía?”, 3.
} 
Ahora bien, cabe preguntarse por qué si los teósofos son una sociedad secreta, entonces, por qué se dan a conocer públicamente y por qué hacen públicas sus doctrinas hasta en periódicos de circulación corriente. La respuesta a esta interesante pregunta la da el filósofo francés Serge Hutin en su obra Sociedades Secretas en la cual establece que no es lo mismo hablar de "sociedades secretas iniciáticas" que de "sociedades secretas políticas". Las primeras no buscan en absoluto ocultar su existencia (salvo cuando son perseguidas), su historia, sus instituciones, sus doctrinas y sus miembros generalmente son muy conocidos 50 .

Sociedades iniciáticas como la teosofía solo guardan en secreto algunas de sus ceremonias y rituales de los cuales no pueden participar personas profanas y son iniciáticas, porque sus afiliados pasan por un proceso de iniciación. Cabría agregar que a veces también realizan conferencias restringidas al público. En cambio, las sociedades secretas políticas sí ocultan sus objetivos y la identidad de sus miembros, ya que, en ocasiones, tales objetivos implican luchas en contra del poder establecido ${ }^{51}$.

En este contexto habría que decir que no es que la teosofía no juegue un papel político importante sino que, en la mayoría de los casos y de forma convencional, el aspecto político no es la esencia de sus objetivos sino que lo espiritual y lo metafísico. Lo que sucede es que Hutin cree que es muy difícil distinguir entre ambas, ya que, en realidad, algunas sociedades que nacen con un carácter iniciático, posteriormente derivan a objetivos políticos $^{52}$.

Ahora bien, habría que decir que si la teosofía persigue fines predominantemente espirituales la Iglesia católica se vuelve en su contra ${ }^{53}$, a pesar de que la teosofía trate de integrar sus postulados con los del cristianismo ya que simple y llanamente -el catolicismo- la verá como una impostora que amenaza con robarle no solamente protagonismo sino también la verdad y la autoridad incuestionables. Jinarajadasa establece que, aunque sabe que la Iglesia católica moderna condena las doctrinas teosóficas, -a través del tiempo-, también han habido algunos esfuerzos por conciliar ambos sistemas mediante obras como: Transacciones de la Sociedad de Filadelfia publicada por feligreses católicos en 1697, Introducción a la teosofía vista como los misterios de Cristo, obra dirigida específicamente a estudiantes de universidades, colegios y escuelas cristianas y Misceláneas teosóficas y guía de lo espiritual, publicada en 1675 por el sacerdote católico Miguel de Molinos. Todas con el ánimo de aprovechar las ideas teosóficas por la religión cristiana $^{54}$.

En esta misma línea de ideas, Annie Besant consideraba que la Iglesia católica en los actos más importantes siempre utilizaba el latín como una especie de "mantra" que

\footnotetext{
${ }^{50}$ Serge Hutin, Las sociedades secretas (Madrid: Ediciones Siruelas S.A., 2008), 24-25.

${ }^{51}$ Hutin, Las sociedades secretas, 24-25.

${ }^{52}$ Hutin, Las sociedades secretas, 24-25.

${ }^{53}$ José María Caro, ¿Qué es la teosofía? (Santiago de Chile: Difusión chilena, 1942), 15. "Los teósofos no temen sostener que el hombre es Dios, que fuera de Él no hay ni puede haber nada. Si tratáis de averiguar a qué clase de panteísmo pertenece, no llegaréis a descubrirlo, porque unas veces se os dará a entender el panteísmo materialista inmanente, otras el emanantista transeúnte, otras el panteísmo idealista. En todo caso se os afirma perentoriamente la unidad de todo ser con el Absoluto o con Dios. La refutación del panteísmo la tenéis en cualquier texto de filosofía".

${ }^{54}$ Jinarajadasa, “¿Qué es la teosofía?", 3.
} 
actuaba, no como una lengua muerta, sino como una especie de fuerza vibratoria entre este mundo y los mundos invisibles. Estas vibraciones producían sonidos que a su vez constituían "palabras de poder" que afectaban los mundos supra-físicos, especialmente, durante la misa. Estos "mantras" eran parte esencial de todo sacramento ${ }^{55}$, de hecho, Besant escribió un libro titulado El cristianismo esotérico, los misterios de Jesús de Nazareth, cuyo objetivo era reafirmar las profundas verdades del cristianismo, que generalmente eran desatendidas e incluso negadas por los materialismos ${ }^{56}$. Ahora bien, una vez formada una idea de lo que es teosofía es conveniente explicitar cuáles son sus postulados esenciales.

\section{Principios esenciales de la teosofía según Jinarajadasa}

Una sola causa de todo lo existente ${ }^{57}$ : este principio sostiene que todo lo creado tiene un solo origen, (hermandad-panteísmo) llámesele Dios, Padre o como quiera llamársele ${ }^{58}$, el ejemplo clásico al cual hace referencia la teosofía es al de San Francisco de Asís, quien llamaba a los animales sus hermanos, con la aclaración que estos hermanos están en un grado inferior en el proceso de evolución, pero hay también otros seres que están en un grado superior a la humanidad y son los llamados maestros, iluminados, santos o gurús. Esto es lo que la teosofía conoce como "jerarquía de los seres"59.

Según Jinarajadasa, además del Uno existen legiones de logos secundarios, que rigen distintas congregaciones de sistemas solares, por lo que habrían innumerables huestes de inteligencias espirituales, que precisamente son los devas, arcángeles y ángeles de las religiones tradicionales, así como distintas graduaciones de espíritus que residen en los cuerpos humanos hasta llegar a las inteligencias sub-humanas y las que aún no han despertado ${ }^{60}$.

Esta Causa Primera estaría inmanente en todas las causas secundarias ${ }^{61}$, por lo tanto, en todas las cosas. Los filósofos herméticos, según Jinarajadasa, formularon esta verdad: "mientras que todas las cosas están en el todo es igualmente cierto que todo está en todo".

\footnotetext{
55 Annie Besant, "Cristianismo esotérico o los misterios menores”, La Prensa, 23 de octubre de 1933, 3.

${ }^{56}$ Annie Besant, El Cristianismo esotérico, los misterios de Jesús de Nazarth (Buenos Aires: Editorial Claridad, 1944), en The Conscious Living Foundation, https://www.consciouslivingfoundation.org/ebooks/Span14/Annie\%20Besant\%20$\% 20$ Cristianismo\%20esoterico.pdf

57 Jinarajadasa, “QQué es la teosofía?”, 3.

${ }^{5}$ Diario Oficial, Suplemento La República, "Discurso de bienvenida del Presidente Martínez a las delegaciones asistentes a la celebración del Primer Centenario de la Universidad de El Salvador”, 20 de febrero de 1941, 2. "Por la síntesis filosófica (teosofía) los sabios de todas las épocas descubrieron la energía universal que se manifiesta en el mundo material, emocional, mental y espiritual, porque no hay más que "una" energía, la de Dios, el creador".

${ }^{59}$ Cronos, "Pronto nos visitará el Dr. Jinarajadasa: algunas de sus ideas acerca de la teosofía", 17 de octubre de 1938,3 .

${ }^{60}$ Cronos, "Pronto nos visitará, 3.

${ }^{61}$ Diario Nuevo, "Interesante plática del Sr. Presidente Martínez en el Pro-patria”, 25 de febrero de $1943,3$. "El hombre no es como afirma Haeckel, un producto ciego de la evolución natural. Por el hecho de llevar dentro de sí una conciencia que lo guíe en el sendero de la vida, proviene de un origen superior. Es chispa divina, animada por la aspiración de volver a la fuente de donde procede".
} 
Para Jinarajadasa, este principio también fue sustentando por el cristianismo cuando Pablo dijo: “...Porque en Él (Dios) vivimos y nos movemos y somos”. (Hechos XVII, 28). ¿No sabes que eres el templo de Dios y que Dios mora en ti? (I Corintios III, 16). Jinarajadasa también cita al sacerdote jesuita Gerónimo Ripaldi quien se cuestiona ¿Dónde está nuestro Dios, Señor y Padre? en todo lugar por esencia, presencia y potencia. (Catecismo páginas 51 y 52 , edición de 1927) ${ }^{62}$.

Para Jinarajadasa, esta Primera Causa Absoluta estaba fuera de la comprensión de todo conocimiento humano en el sentido de que era un Dios desconocido, sin nombre, inmanifestado, que solo era posible conocer a través de su actividad: amor, sabiduría y voluntad y que en todas las religiones se había expresado en una naturaleza trina. En el cristianismo a través del Padre, el Hijo y el Espíritu Santo, en Egipto, mediante Isis, Osiris y Horus, en los hindúes, por medio de Nara, Nari y Viradj, en los Persas en Agni, Vayú y Surya. Estos tres sujetos han sido intrínsecamente inseparables, pero, según el hindú, en ocasiones prima uno de ellos y es lo que los antiguos filósofos llamaban "medidas divinas", que era una manifestación de la actividad cósmica ${ }^{63}$.

El Dios que describe Jinarajadasa se asemeja mucho al de Feuerbach para quien Dios es solo una atribución de las cualidades humanas. El filósofo alemán, en este mismo sentido, desenreda la creencia de en un Dios inmanente en tres, que surge, según él, a partir de que Dios es una entidad autárquica, lo cual quiere decir que se basta a sí mismo, pero el problema para la teología viene dado en el hecho de que este Dios desde su solipsismo se ve imposibilitado a practicar el amor ${ }^{64}$, del cual habla Jinarajadasa.

Para poder amar, Dios necesita de otro diferente a él en cuanto a su individualidad aunque no en cuanto a su esencia y es así como surge el Hijo. Del amor unido a la inteligencia surge el Espíritu Santo que representa la unión o lazo fraternal entre las dos divinas personas. En otras palabras, para Feuerbach, el misterio de la trinidad es una simple proyección humana de la necesidad social que representa la unión entre Dios y el hombre $^{65}$. En base a esta relación podría explicarse porque es un credo que aparece arquetípicamente en las religiones más importantes del mundo.

Feuerbach explica que el Espíritu Santo funciona como un ente femenino (erótico) a manera de madre para constituir así la sagrada familia. El filósofo alemán coincide hasta cierto punto con el positivismo en establecer que las religiones son un reflejo de la etapa ingenua de la humanidad. Desde su perspectiva, el misterio de la trinidad es una contradicción entre monoteísmo y politeísmo, la cual se explica por el solo hecho de ser

\footnotetext{
${ }^{62}$ Jinarajadasa, “¿Qué es la teosofía?”, 3.

${ }^{63}$ Cronos, "Pronto nos visitará el Dr. Jinarajadasa: algunas de sus ideas acerca de la teosofía", 15 de octubre de 1938, 3. "La segunda grande y universal verdad religiosa de la teosofía es la trinidad de un logos al manifestarse. Adopta este término la teosofía tomándolo de Platón, de Filo y del cuarto evangelio...procediendo de las profundidades de la existencia "Una" que sobrepasa toda comprensión y todo lenguaje, un logos, imponiéndose a sí mismo un límite y circunscribiendo voluntariamente su propia área de acción, deviene un "Dios manifestado" y crea un universo. Esta Deidad auto-creadora se desenvuelve en triple forma: voluntad: que exhala de sí y aspira dentro de sí los mundos, sabiduría: manifestando los dos aspectos de vida y forma entre los cuales ha de tejerse la contextura del universo y la mente universal fuente creadora de todas las formas arquetípicas que han de ser producidas y elaboradas en la materia durante la evolución del universo, es actividad".

${ }^{64}$ Ludwig Feuerbach, La esencia del cristianismo (Buenos Aires: Editorial Claridad, S.A, 2006), 83.

${ }^{65}$ Feuerbach, La esencia del cristianismo, 83.
} 
una mera invención humana ${ }^{66}$. En este punto puede establecerse que la teosofía de forma similar a la filosofía religiosa especulativa, trata de conservar el misterio de la trinidad contra la inteligencia atea.

En un sentido religioso, Dios está manifiesto en todas las cosas siendo su "vida divina" el espíritu que anima la creación. Jinarajadasa dice que cada filósofo o fundador de una religión ha representado de una forma diferente la Causa Primera. Para Vyasa fue el Sol, para Hermes la luz, para Zoroastro el fuego y para Orfeo la armonía, todas diferentes formas de visualizar a la misma verdad única ${ }^{67}$. En su opinión, no se puede ser un verdadero teósofo mientras no se haya tenido un encuentro personal con Dios ${ }^{68}$.

\section{Imagen 4}

"La Unidad de la vida", según Albert Einstein

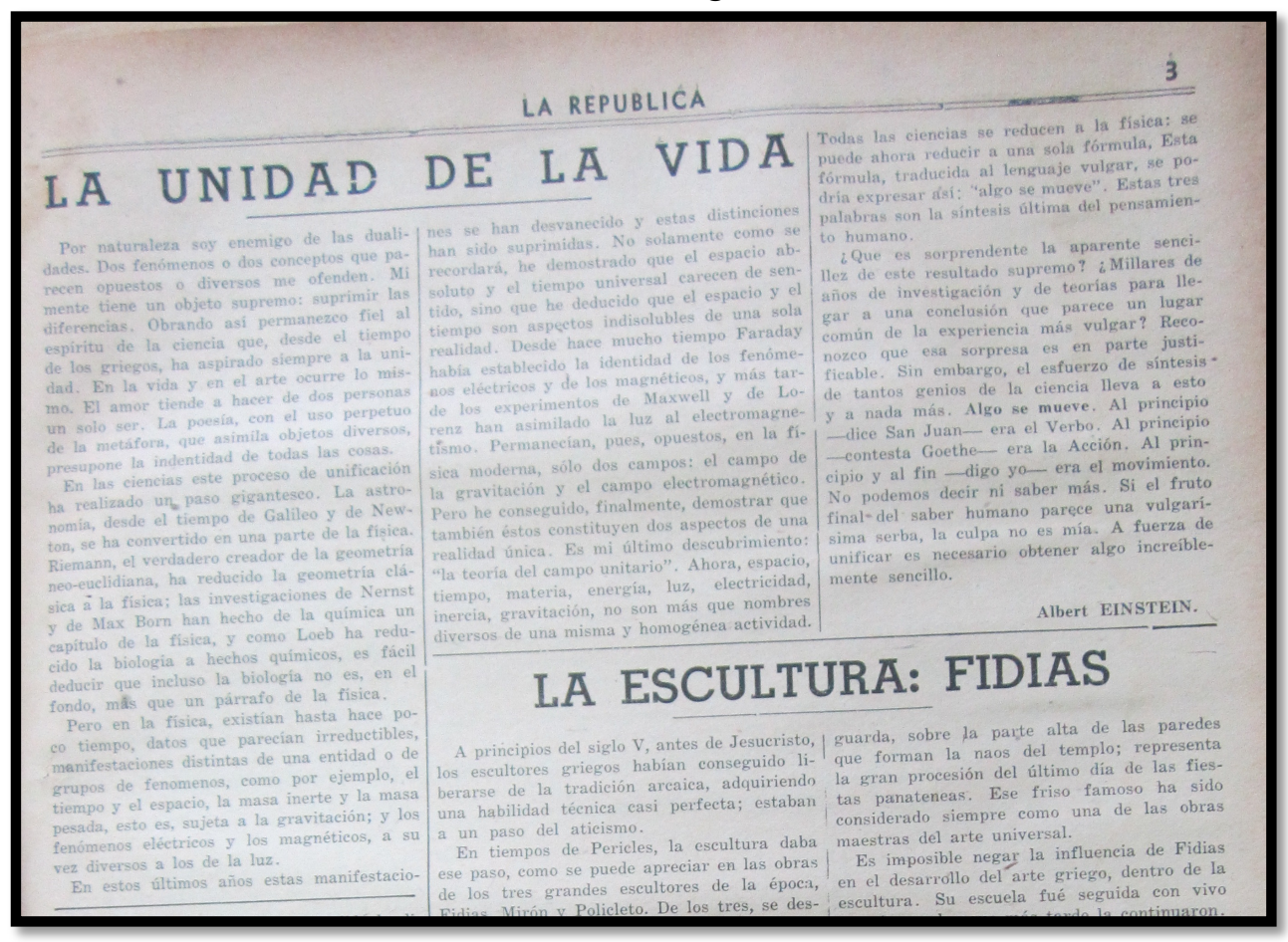

Fuente: Albert Einstein, "La Unidad de la vida", Diario Oficial, Suplemento La República, 4 de abril de 1941, 3.

La hipótesis de este artículo es que la teosofía quiso fundamentar sus principios en la ciencia. Según este pequeño fragmento de Einstein habría una corroboración por parte de la ciencia oficial del principio de una sola causa. En primer lugar todas las ciencias podrían fundamentarse en una sola primera y única ciencia: la física. Luego la teoría del campo unificado comprobaría que todas las fuerzas de la naturaleza se pueden resumir en una sola: "Ahora espacio, tiempo, materia, energía, luz, electricidad, inercia, gravitación, no son más que nombres diversos de una misma y homogénea actividad". O sea, según Einstein la causa de todo es "el movimiento". Einstein también afirmaría que para San Juan la causa primera fue "el verbo" y para Goethe "la acción". El otro punto en el que se sostiene esta hipótesis es que para Einstein ciencia y religión se podían complementar, por tanto, todas estas ideas se intentaron de integrar al imaginario teosófico.

\footnotetext{
${ }^{66}$ Feuerbach, La esencia del cristianismo, 26, 84, 257.

${ }^{67}$ Jinarajadasa, “¿Qué es la teosofía?”, 3.

${ }^{68}$ La Prensa, "De las enseñanzas del Dr. C. Jinarajadasa", 24 de octubre de 1938, 3.
} 
Ley de evolución: Es la base fundamental en el proceso de toda manifestación, ya sea de fenómenos que pueden ser percibidos por los sentidos o no. La teosofía no reconoce el estancamiento absoluto, ni estados o penas perpetuas sino que cree que todo "ser" tiene una ruta evolutiva ascendente. En los individuos que están más evolucionados, Dios se manifiesta con mayor amplitud y es por eso que Jesús le dijo a los judíos: "Vosotros sois dioses, e hijos todos vosotros del Altísimo" (Salmo 82, 6) ${ }^{69}$.

Según Jinarajadasa, en general, las religiones han acelerado el proceso de evolución de la raza humana mediante la enseñanza de las verdades fundamentales relativas al "ser" y sus relaciones con la Causa Primera de acuerdo con el nivel de evolución alcanzado en cada época concreta. Lo que sucede es que estas verdades se han sabido adaptar a los tiempos para poder subsistir siempre en constante reinvención en donde solo cambia la forma y el mensajero pero nunca el mensaje ${ }^{70}$.

Ley rigurosa de causa y efecto: Es el principio que establece que todo permanece en movimiento eterno hasta llegar a la Causa Primera o Arquetipo que le dio origen a todo. (Muy similar a la concepción del motor inmóvil aristotélico que mueve sin ser movido). Según esta ley, no existe la fortuna, la suerte, las casualidades o designios caprichosos de un Dios creador, por lo que todo está sujeto al principio natural de causación ${ }^{71}$. Jinarajadasa pone el ejemplo bíblico de Gálatas VI, 7, cuando San Pablo dijo: "No te engañes. Dios no puede ser burlado: que todo lo que el hombre siembra eso también cosechará". En las religiones orientales este principio fue conocido como "karma", denominación que permanece en la literatura teosófica ${ }^{72}$ :

Mientras que existen muchos individuos que creen que pueden asesinar, robar, calumniar y cometer otras tropelías burlando la justicia humana o ser perdonados mediante doctrinas torcidas diciendo misas o arrodillándose ante santos (...) el verdadero teósofo cree en cambio que sólo las buenas acciones son las que pueden redimir al ser humano y que el que obra mal tiene que ser castigado, sin que valgan arrepentimientos, ni oraciones para eludir el justo castigo. Esa ley es la de compensación, karma o renacimiento ${ }^{73}$.

El filósofo hindú Kapila también expresó: “el efecto es la causa reproducida en otra forma, el efecto nunca es esencialmente diferente de la causa: es la causa limitándose a tomar forma". Jinarajadasa para darse a entender más contemporáneamente, tomó un ejemplo de la alquimia: "el ácido sulfúrico al actuar en el sodio da origen al sulfato de sodio, sal muy diferente de sus componentes. El ácido sulfúrico que produce esa sal está

\footnotetext{
${ }^{69}$ Jinarajadasa, “¿Qué es la teosofía?”, 3.

${ }^{70}$ Jinarajadasa, “¿Qué es la teosofía?”, 3.

${ }^{71}$ Diario Oficial, Suplemento La República, "Plática filosófica del General Don Maximiliano Hernández Martínez", 18 de septiembre de 1942, 4. "Acudamos a La Biblia en nuestro apoyo. En uno de su versículos dice un texto sagrado: El mal que haces lo pagarás y con una cuarta más. Muy sabios eran los que escribieron aquella obra y grande era el conocimiento que tenían de las cosas del alma. No solamente los actos que ejecutamos en perjuicio de los demás se cobra en forma de dolor, sino también las ociosas palabras que decimos y los malos pensamientos que formamos".

${ }^{72}$ Jinarajadasa, “QQué es la teosofía?”, 3.

${ }^{73}$ Roger, "Concepto errado que de la teosofía tienen algunos", El Cronista, 31 de octubre de 1938, 7.
} 
inmanente en el sulfato de sodio. En cualquier momento mediante un procedimiento adecuado se puede separar el sodio de la sal y aparece el ácido sulfúrico”. De esta misma forma, en todos los cuerpos químicos compuestos habría una inmanencia de los elementos que los componen como es el caso del hidrogeno en el agua y también se aplica en la electricidad, el magnetismo y en todos los agentes activos de la naturaleza ${ }^{74}$. Este principio también habría sido sostenido por Santo Tomás de Aquino cuando en la Summa Teológica, $1^{a}$ parte, cuestión IV, artículo 2 dijo:

Todo lo que hay de perfección en el efecto se ha de encontrar en la causa efectiva. Luego es claro y evidente que el efecto preexiste en la causa agente (...) luego siendo Dios la primera causa efectiva de todas las cosas, las perfecciones y el ser por lo tanto de todas ellas han de preexistir en Él de un modo eminentísimo ${ }^{75}$.

Ley de supervivencia o de eternidad del espíritu: Consiste en que ninguna manifestación física puede ser destruida en los procesos de la naturaleza, solo existe la transmutación o cambio, pero nunca la aniquilación ${ }^{76}$. En este sentido, los seres humanos al morir solo experimentan una transformación tal como dijo Pablo: "todos seremos transformados" (I de Corintios XV-51), pero además Jinarajadasa también puso el ejemplo científico del átomo más diminuto de la materia que no puede ser destruido solo cambiar en su forma, conservando la esencia ${ }^{77}$, aseveración que se asemeja a la primera ley de la termodinámica que dice que "la energía no nace ni se destruye solo se conserva o se transforma".

Jinarajadasa establece que este principio, en el ámbito religioso, se cumple a través de la reencarnación, creencia $^{78}$ que sabe no es aceptada mayoritariamente en el mundo occidental, pero afirma que ha habido autores occidentales como David Hume que han afirmado que es la única forma posible de inmortalidad del alma, inclusive, expresó que esto también fue sostenido por Cristo cuando dijo: "y si le quieres recibir, Él es aquel que Elías dijo que debía de venir" (Mateo XI, 14) ${ }^{79}$. En todas estas explicaciones es muy evidente como Jinarajadasa trata de hibridar religión, filosofía y ciencia.

Pero en realidad, Hume no dice que cree en la reencarnación sino que literalmente dice: "la metempsicosis es, por tanto, el único sistema en favor de la inmortalidad del alma

\footnotetext{
${ }^{74}$ Jinarajadasa, “¿Qué es la teosofía?”, 3.

${ }^{75}$ Swami Vivekananda, Conferencias Teosóficas (Barcelona: Antonio Roch Editor, sfp), 11.

${ }^{76}$ A. G. Tavel, "Teosofía", El Cronista, 15 de octubre de 1938, 1 y 8. "Como las chispas vuelven a las llamas y se funden en ellas, así dicen que nosotros volvemos a nuestra fuente original, esto lógica y racionalmente no es inmortalidad, es tesis materialista ni más, ni menos. Cuando el ser humano muere, muere su cuerpo y se ve dispersado y disuelto en los elementos que sirvieron a su construcción." El Dr. A. G Tavel fue director de la escuela filosófica trascendental "El Nuevo Pensamiento" y del Instituto Bíblico de Honduras. El Cronista le brindó algunos renglones para aclarar ciertas dudas sobre teosofía.

${ }^{77}$ Jinarajadasa, “¿Qué es la teosofía?”, 3.

${ }^{78}$ Cronos, "Pronto nos visitará el Dr. Jinarajadasa: algunas de sus ideas acerca de la teosofía", 17 de octubre de 1938, 3. "La inmortalidad del alma es parte integrante de la filosofía teosófica como deducción inevitable de la identidad de naturalezas del ser humano y del Ser Universal. La continuidad de conciencia es igualmente inevitable puesto que el "yo" es consciente y eterno en el devenir de todas sus experiencias inspeccionándose sucesivamente a sí misma en sus memorias o recuerdos".

${ }^{79}$ Jinarajadasa, “QQué es la teosofía?”, 3.
} 
al que la filosofía puede prestar alguna atención". Hume solo establece que dicha teoría merece ser estudiada, pero nunca asumida. Por el contrario, el filósofo escocés trata de destruir toda prueba moral, metafísica o física que sirva para respaldar dicha teoría en base a la razón natural y la observación empírica ${ }^{80}$ :

La muerte es el fin inevitable. Y, sin embargo, la naturaleza no nos hubiese inspirado una aversión natural a ese fin. Debe sospecharse de toda doctrina que es favorecida por nuestras pasiones y las esperanzas y miedos que han favorecido la doctrina de la inmortalidad son sobremanera obvios ${ }^{81}$.

Principio de vibración ${ }^{82}$ : Nada se conserva en reposo, todo está en movimiento, todas las cosas vibran aún la materia más densa. Aquellas cosas que aparentemente son estáticas, en realidad, están en vibración constante ${ }^{83}$. Salarrué sobre este tema pensaba que la materia y el espíritu solo eran los dos extremos de una misma cuerda acondicionados en base a vibración ${ }^{84}$. Para Hernández Martínez, todo era vibración y toda vibración se transformaba en sonido y todo sonido se transformaba en luz. Algunos seres humanos, según él, estaban más capacitados que otros para oír ciertas vibraciones sutilísimas de la energía y algunos también podían ver cómo estas vibraciones se transformaban en luz ${ }^{85}$.

La base filosófica de este principio está en Orfeo quien predicó la naturaleza divina de la armonía. Estableció que la armonía del universo radicaba en lo interno del hombre, que lo único que este tenía que hacer era vibrar al mismo nivel de lo creado, es decir, entrar en comunión con todo lo creado y con la Causa Única ${ }^{86}$ y también en Pitágoras para quien el Cosmos era un orden perfecto, una armonía universal. El ser humano podía interpretar y transmitir las ondas de la existencia que emanaban permanentemente del Sol, el músico Supremo, el Creador ${ }^{87}$. Al referirse a este principio, el teólogo y químico español Enrique Miret Magdalena expresó:

La filosofía venida de Oriente ha sostenido que todo el mundo es vibración. Y, efectivamente, la nueva química y la nueva física descubren, siglos después de esa olvidada y antiquísima afirmación hindú, que las moléculas vibran dando 20

\footnotetext{
${ }^{80}$ David Hume, Sobre el suicidio y otros ensayos (Madrid: Alianza Editorial, 1988), 18-145.

${ }^{81}$ Hume, Sobre el suicidio y otros ensayos, 146.

${ }^{82}$ Diario Oficial, Suplemento La República, "Plática del General Martínez versó sobre el dominio de la mente y las emociones", jueves, 3 de diciembre de 1942, 4. "Las vibraciones mentales que engendran aquellas dos emociones (amor y odio) ejercen una influencia marcada sobre nuestra contextura física. Se diría que el cuerpo humano adquiere un ritmo semejante al de las emociones que dominan en determinado instante el "yo" espiritual".

83 Jinarajadasa, “QQué es la teosofía?”, 3.

${ }^{84}$ Museo de la Palabra y la Imagen, Espectroscopio, una columna de Salarrué: acotaciones, comentarios y especulaciones en La Metafísica, sin fecha, bajo clasificación: SV-MUP1-I (1.2-F20.1).

${ }^{85}$ Maximiliano Hernández Martínez, "La imperfección del ser humano", AGN, sección: familiares y personales, fondo: MHM, serie: 05, pláticas doctrinales, caja 2. Exp. 52, 1, $1^{\circ}$ de diciembre de 1942.

${ }^{86}$ Hernández Martínez, "La imperfección del ser humano", 1.

${ }^{87}$ Patricia Caniff, Pitágoras, grandes iniciados (Madrid: Ediciones y distribuciones Mateos, 1998), 69.
} 
millones de oscilaciones por segundo, y los electrones mucho más: 6 billones por segundo $^{88}$.

Otra sostenedora de este principio ya dentro del mundo occidental, es María Zambrano, discípula de Ortega y Gasset y Xavier Zubiri, quien se identificaba profundamente con la ética de Spinoza y las Enéadas de Plotino. Zambrano se interesó mucho por los planteamientos pitagóricos, los cuales se encuentran presentes en su pensamiento musical ${ }^{89}$. En realidad, toda la estructura de su filosofía, a excepción de lo que le aportan los connotados autores occidentales ya mencionados, es muy semejante a la teosofía.

Zambrano creía que Plotino era la universalidad de una religión de la luz que había influido en toda su obra, pero principalmente en su poesía -y la cual creía- se había originado en el Libro de los muertos de los egipcios. También sostuvo una visión irracionalista y anti-positivista de la filosofía y se interesó mucho por la idea de la reencarnación en base a los escritos póstumos del padre de la antropología filosófica moderna Max Scheler Ordo Amoris y Muerte y supervivencia y al igual que los teósofos concebía al hombre como un trozo del cosmos. Zambrano sentía mucho aprecio por la filosofía oriental, conoció los ritos órficos y sintió simpatía por el culto a Dionysios. La teoría del ritmo pitagórica, sin duda, fue muy importante para la filósofa española ${ }^{90}$ :

Tal vez la vencida tradición del pitagorismo fuese la portadora de este saber del ritmo del pensamiento, en sus formas vivientes y eficaces. Como tantas otras tradiciones de saber oscurecidas por el aristotelismo reinante, no se llegó a extinguir. Prosiguió su vida heterodoxa en forma de saber secreto, propio para los iniciados, en los linderos o dentro ya de la teosofía. Pero de estos saberes inextinguibles, brota un día la inspiración que parece infiltrarse o revivir dentro de las formas más ortodoxas de saber triunfante ${ }^{91}$.

\footnotetext{
${ }^{88}$ Enrique Miret Magdalena, Occidente mira a Oriente: su mensaje de sabiduría y desarrollo humano (Barcelona: Plaza y Janés Editores S.A., 1999), 162.

${ }^{89}$ María Zambrano, Hacia un saber sobre el alma (Madrid: Alianza Editorial S.A., 2001), 11-12.

${ }^{90}$ Zambrano, Hacia un saber sobre el alma, 13, 24, 25, 26, 30, 31, 46.

${ }^{91}$ Zambrano, Hacia un saber sobre el alma, 55.
} 


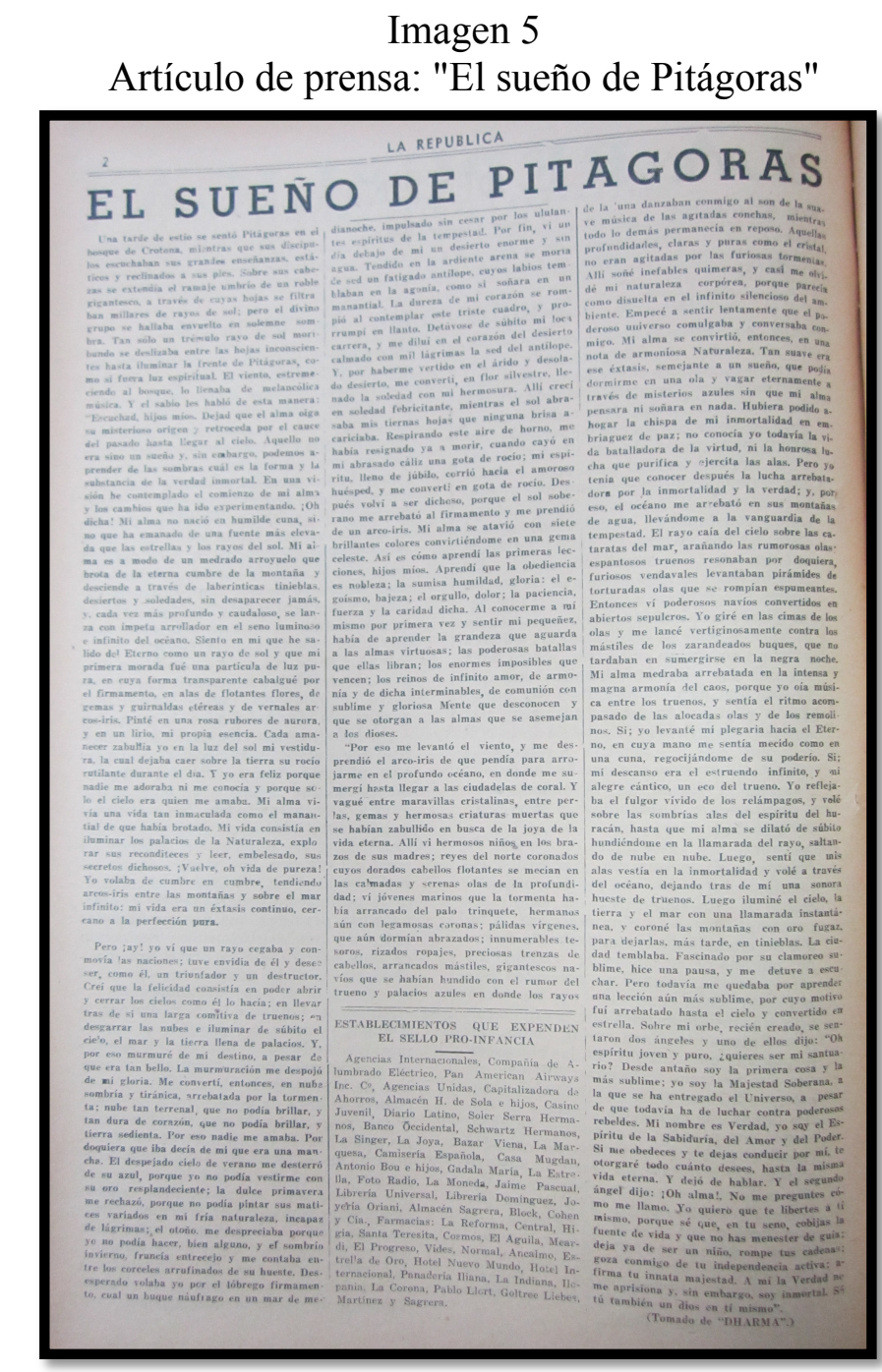

Fuente: "El sueño de Pitágoras”, Diario Oficial, Suplemento La República, 12 de diciembre de 1942, 2.

En el siguiente párrafo puede advertirse la teoría del ritmo de Pitágoras: "Allí soñé inefables quimeras, y casi me olvidé de mi naturaleza corpórea, porque parecía como disuelta en el infinito silencioso del ambiente. Empecé a sentir lentamente que el poderoso universo comulgaba y conversaba conmigo. Mi alma se convirtió, entonces, en una nota de armoniosa Naturaleza. Tan suave era ese éxtasis, semejante a un sueño, que podía dormirse en una ola y vagar eternamente a través de misterios azules sin que mi alma pensara ni soñara en nada. Hubiera podido ahogar la chispa de mi inmortalidad en embriaguez de paz (...) mi alma medraba arrebatada en la intensa y magna armonía del caos, porque yo oía música entre los truenos, y sentía el ritmo acompasado de las alocadas olas y los remolinos. Sí; yo levante mi plegaría hacia el Eterno en cuya mano me sentía mecido como en una cuna, regocijándome de su poderío... ".

José Vasconcelos por su parte, también creía que la actividad estética obedecía a ritmos y regularidades específicos y que la conciencia humana estaba dotada de una capacidad mental o espiritual "a priori" independiente de la lógica, lo cual tampoco significaba caer en un simple sensualismo estético-empírico. Para el filósofo mexicano, pensar en algo hermoso, producía una relación melódica rítmica que complacía a la existencia del espíritu, según él, los intelectualistas veían al espíritu como una operación 
lógica, pero los místicos lo ubicaban como una operación rítmico-estética a través de la poesía, la música, la plástica o la pintura. La gran diferencia entre el intelectualista y el artista, era que el primero trabajaba con ideas y el segundo con imágenes ${ }^{92}$ :

El ritmo del músico va adquiriendo entonces caracteres por definición de nuestro ritmo interior y sus posibilidades (...) ordena el ritmo, en la línea simple del tiempo, dos sonidos heterogéneos o varios sonidos heterogéneos y los repite a intervalos constantes. Sin quererlo, ha medido el tiempo, pero no le interesa la medida, sino el efecto de ésta, o sea realizar una especie de solución vital de la existencia de los seres de sonido en el campo de la conciencia. La medida depende de la fisiología, pero el arreglo es astucia del alma ${ }^{93}$.

Este concepto de la armonía universal, finalmente lo encontramos en Leibniz, para quien la armonía no era simplemente el mero acuerdo entre unas cosas y otras, sino la máxima exigencia de inteligibilidad de la realidad y de la esencia de las cosas mismas. Para Leibniz, había una armonía entre materia, tiempo y movimiento y consideraba que existía una unidad de la substancia. Leibniz, según Bernardino Orio de Miguel, se vio muy influenciado por la teosofía, ya que su familia era amiga del famoso teósofo belga Francisco Mercurio van Helmont. Leibniz aceptaba la existencia de un átomo metafísico, que era el Uno y la ley de causalidad ${ }^{94}$ :

No se abría pues para Leibniz, en el horizonte conceptual de su tiempo, más que la vieja tradición espiritual teosófica, alquímica y cabalística, en la que de joven se había iniciado y que nunca abandonó, pero que ahora, con las nuevas herramientas conceptuales proporcionadas por la matemáticas y la dinámica, ofrecía a sus ojos la base más amplia de la anhelada Philosophia Perennis, a cuya construcción él podía aportar justamente el armazón racional que necesitaba. Si Dios es espíritu, decía la tradición teosófica, toda substancia creada ha de serlo. El espíritu gobierna al mundo; el espíritu es vida y la vida ${ }^{95}$.

El espiritualismo de la tradición teosófica era vitalista o pampsiquista, por tanto $L a$ monadología de Leibniz también lo era. Leibniz creía que todas las substancias individuales se relacionaban, ya que estaban concatenadas en una armonía originaría y preestablecida del Cosmos y su principio de analogía consistía, precisamente, en que una substancia se expresaba en otra, ya que todo era una concentración del Universo en armonía. Según Bernardino Orio de Miguel, en la Hypothesis physica nova de 1671 recogió la concepción teosófica del macro y del microcosmos y la idea de los mundos incluidos en otros mundos. Leibniz, de forma muy similar a Vasconcelos también creía que

\footnotetext{
92 José Vasconcelos Calderón, Estética, Antología de Gerardo González Macgregor (México DF: Ediciones Oasis S.A), 191 y 194.

${ }^{93}$ Vasconcelos Calderón, Estética, 207.

${ }^{94}$ Bernardino Orio de Miguel, "El principio de analogía en Leibniz", Revista Enrahonar 14 (1988): 34-35, 36-55.

${ }^{95}$ De Miguel, El principio de analogía en Leibniz", 38.
} 
había una continuidad rítmica entre las obras de la naturaleza y las obras de arte ${ }^{96}$ La filósofa española Cinta Canterla González también reconoce la influencia de la tradición teosófica en Leibniz y Newton:

Y es que tanto Newton como Leibniz habían recibido influencias de la tradición neoplatónica. Newton en concreto las había recibido de la alquimia, la mística, la teosofía (por la que su heterodoxia religiosa le hizo interesarse) y el neoplatonismo de Cambridge, al menos el de la filosofía de Moore. Leibniz, del neoplatonismo y de la logosmistik alemana. La concepción vitalista de los componentes de la materia (en su versión física) y de la realidad (en la filosófica) se encuentran en la Edad Media tanto en la alquimia como en filosofías y teosofías tales las de Nicolás de Cusa, G. Bruno, Eckart, y más tarde Böhme" ${ }^{97}$.

Principio de libertad y tolerancia religiosa: Así como los seres humanos se encuentran en diferentes grados evolutivos, también hay algunas religiones que están más adaptadas al desarrollo espiritual que otras, por lo tanto, estas últimas son las que más convenía seguir $^{98}$. Todas las religiones son una unidad, todas son raíces del mismo árbol, que en el transcurso del tiempo dan su fruto, porque todas se encuentran amparadas ante la misma "sabiduría divina". La teosofía pretende ser una explicación armónica de todas sus verdades parciales, como una especie de síntesis de todas sus visiones ${ }^{99}$.

Jinarajadasa explica que los mahometanos crecieron en condiciones materiales muy precarias, en terrenos estériles y desiertos, por lo que se tornaron violentos. Ante esto, su maestro Mahoma les enseñó el principio de resignación a la voluntad divina y el monoteísmo: "sólo existe un solo Dios y Mahoma es su profeta". En el Judaísmo, el principio fundamental es la rectitud divina y como derivación de éste vino el cristianismo con Jesús quien trajo su mensaje de amor a la humanidad. Jinarajadasa reconoce que el cristianismo es la religión que más ha predominado en Occidente, según el teósofo, Cristo invitó a encontrar nuestro propio Cristo interno de esta manera: "De cierto os digo que el que crea en mí, las obras que yo hago él también las hará (San Juan XIV, 12) ${ }^{100}$.

Cristo enseñó el ideal de servicio y el amor muto, mandó a todos a verse como hermanos. Lo que Jinarajadasa concluye, en definitiva, es que cada religión ha formado un sistema y ha cumplido su misión en el tiempo que le ha tocado propagar la forma de verdad que ha tenido que ser dada al mundo, pero que con el paso del tiempo, pierden su vigencia y en el afán de cada una de prevalecer sobre las demás, es que se han desatado las grandes guerras religiosas que tanto han dañado a la humanidad. Es importante aclarar que para los teósofos, las verdades enseñadas por sus líderes no son de su invención, sino que

\footnotetext{
${ }^{96}$ De Miguel, El principio de analogía en Leibniz", 43-52.

${ }^{97}$ Cinta Canterla González, "Neoplatonismo, filosofía natural y misticismo fuentes ocultas del romanticismo en el Kant precrítico", Cuadernos de Ilustración y romanticismo 1 (1991): 166.

${ }^{98}$ Diario Nuevo, "Plática del Sr. Presidente Martínez sobre la carta atlántica", $1^{\circ}$ de abril de 1943, 3. "La libertad de elegir religión es básica para el hombre. Cada uno de nuestros semejantes se encuentra en un grado de evolución. De acuerdo con él escoge la fe que mejor se acomode a sus tendencias y modalidades. Busca a Dios en el plano de espiritualidad en que se encuentra. De allí que no se puedan imponer credos."

99 Jinarajadasa, “¿Qué es la teosofía?”, 3.

100 Jinarajadasa, “¿Qué es la teosofía?”, 3.
} 
estas ya se encuentran en los libros sagrados llámense: Vedas, El Corán o La Biblia ${ }^{101}$. Además, mediante la exposición de estos principios la teosofía pretende ser un conocimiento que es superior a toda sabiduría humana, es decir, revelado por las distintas deidades y que será comprobado paulatinamente por las distintas ciencias ${ }^{102}$.

\section{Conclusión: valoración crítica de los principios teosóficos}

Al hacer una valoración crítica de estos principios puede establecerse que sostienen una doctrina que desde el punto de vista académico es una pseudo-religión, una pseudofilosofía y una pseudo-ciencia, ya que, en realidad, en ninguno de estos campos es reconocida como tal, incluso, el tradicionalista René Guénon escribió una obra monográfica titulada El teosofismo, historia de una pseudoreligión (1921).

Hume, además establece que una de las ventajas de la verdadera filosofía es que procura ser un antídoto contra las más burdas supersticiones y la falsa religión, las cuales están basadas a su vez en falsas opiniones. Hume dice que la filosofía no debe dejarse embaucar por la sofistería y que el argumento de la Causa Suprema es un recurso que debería excluirse para siempre de la filosofía ${ }^{103}$. En su Tratado de la naturaleza humana establece que, en realidad, el principio de la causa y efecto no explica nada. Sostiene que un objeto puede ser contiguo y anterior a otro sin ser su causa, o sea, la cualidad de un objeto no depende de la relación causa y efecto: no necesariamente siempre existe una conexión entre dos fenómenos distintos o, en otras palabras, se pueden establecer relaciones causa-efecto falsas ${ }^{104}$ como cuando en la edad media se pensaba que el epiléptico estaba poseído por legiones de demonios que causaban sus convulsiones. Al respecto Bertrand Russell expresa:

Solía pensarse que los cuerpos celestes tenían que moverse en círculos, porque el círculo es la curva más perfecta; que las especies tenían que ser inmutables, porque Dios solo creaba lo perfecto y, por tanto, no había necesidad de mejora; que no debían combatirse las epidemias como no fuera mediante el arrepentimiento, porque eran un castigo del pecado, etc ${ }^{105}$.

Para Hume, no existen pruebas racionales, empíricas o si quiera intuitivas de una Causa Primera como principio autoproductivo y productor de todo lo existente al estilo de las vías que nos ofrece la Summa Teológica para probar la existencia de Dios. La idea de la necesidad de una causa es falsa, porque decir que algo se autoproduce es decir que algo ya existía antes de su existencia, lo cual para Hume además de ser ilógico es ilusorio. Para Hume, muchas de estas causas no son nada más que meros actos de $\mathrm{fe}^{106}$.

\footnotetext{
${ }^{101}$ Salvador Moncada, "Vendrá el Dr. Jinarajadasa”, El Cronista, 25 de agosto de 1938, 6.

102 Diario Nuevo, "El conocimiento superior", 15 de enero de 1935, 3.

${ }^{103}$ Hume, Sobre el suicidio y otros ensayos, 122-138.

${ }^{104}$ Hume, Tratado de la naturaleza humana, tomo I (México DF: Ediciones Gernika S.A., 1992), 105-106.

${ }^{105}$ Bertrand Russell, Por qué no soy cristiano (Barcelona: Editora Hispanoamérica S.A., 1979), 51.

${ }^{106}$ Hume, Tratado de la naturaleza humana, 109-111 y 128.
} 
La académica Dolores López por su parte, manifiesta que la teosofía surgió como una nueva filosofía que trataba de probar la entidad del alma y dotar de un nuevo sentido a la vida, que aunque para sus adeptos constituía un conocimiento legítimo, para sus detractores no fue más que una pseudo-ciencia, aludiendo a que Helena Blavatsky fundó en 1875 la Sociedad de Investigaciones Espiritistas, con cuyos credos simpatizaron multitud de intelectuales y artistas, pero que estaban basados en fraudes ${ }^{107}$. Según ella, dichos fenómenos, en realidad, fueron una amalgama de supersticiones que incluían la telequinesia y la metempsicosis que pudieron haber sido el producto de sugestiones mentales que los teósofos hibridaron con doctrinas asiáticas y el neoplatonismo ${ }^{108}$.

Todo este imaginario también se trató de plasmar en literatura mágica y fabulosa, que combinó elementos naturales con sobrenaturales ${ }^{109}$, en el caso de El Salvador, como la de Salarrué. La difusión de la teosofía y este tipo de narrativas mágicas reflejarían una tensión entre ciencia, para-ciencia, progreso, arte y trascendentalismo, precedido de una época donde predominó el escepticismo y la demostración experimental, es decir, la actitud positivista de ir desmitificándolo todo, aunque las dudas ontológicas de fenómenos como la muerte no estuvieran completamente resueltas ${ }^{110}$.

Desde esta perspectiva, podría decirse que la teosofía y la literatura fantástica, nacieron como un "ansia" o "angustia" de trascender lo empíricamente demostrable, aquello inalcanzable para el entendimiento humano y asequible solo por la "sensibilidad" que quiso presentarse intencionalmente como lo irracional debido a su condición de alteridad $^{111}$, pero al mismo tiempo cayó en falacias e inventos que muchas veces llegaron a la charlatanería, incluso, el mismo Krishnamurti llegó a aceptar que todas las experiencias místicas que vivió durante su etapa teosófica y los supuestos instructores con los que habló fueron irreales $^{112}$.

\section{Fuentes primarias}

Arévalo Martínez, R. "Tres bellos libros de Román Rolland”. La Prensa. $1^{\text {o }}$ de diciembre de 1934.

Besant, Annie. "Cristianismo esotérico o los misterios menores". La Prensa. 23 de octubre de 1933.

Besant, Annie. El Cristianismo esotérico, los misterios de Jesús de Nazareth. Buenos Aires: Editorial Claridad, 1944. En The Conscious Living Foundation. https://www.consciouslivingfoundation.org/ebooks/Span14/Annie $\% 20$ Besant $\% 20$ $\% 20$ Cristianismo\%20esoterico.pdf

Cronos. "Pronto nos visitara el Dr. Jinarajadasa". 15 de octubre de 1938.

\footnotetext{
${ }^{107}$ Dolores López Martín, "El espiritismo, la parasicología y el cuento fantástico hispanoamericano del siglo XIX", Revista Arrabal 5-6 (2007): 39-44.

${ }^{108}$ Martín, "El espiritismo, la parasicología", 39-44.

${ }^{109}$ Martín, "El espiritismo, la parasicología", 39-44.

${ }^{110}$ Martín, "El espiritismo, la parasicología", 39-44.

${ }^{111}$ Martín, "El espiritismo, la parasicología", 39-44.

${ }^{112}$ Pedro López Anadón, Krishnamurti, vida y obra (Madrid: Editorial Oberon, Grupo Anaya, S.A., 2003), 198.
} 
Diario Nuevo. "El conocimiento superior". 15 de enero de 1935.

Diario Nuevo. "Interesante plática del Sr. Presidente Martínez en el Pro-patria". 25 de febrero de 1943.

Diario Nuevo. "Plática del Sr. Presidente Martínez sobre la carta atlántica". $1^{\circ}$ de abril de 1943.

Diario Nuevo. "El Señor Presidente Martínez habló sobre la educación y la instrucción”. 28 de octubre de 1943.

Diario Oficial, Suplemento La República. "Discurso de bienvenida del Presidente Martínez a las delegaciones asistentes a la celebración del Primer Centenario de la Universidad de El Salvador". 20 de febrero de 1941.

Diario Oficial, Suplemento La República. "Plática filosófica del General Don Maximiliano Hernández Martínez". 18 de septiembre de 1942.

Diario Oficial, Suplemento La República. "Plática del General Martínez versó sobre el dominio de la mente y las emociones". 3 de diciembre de 1942.

García P., Rigoberto. “C. Jinarajadasa”. Diario Latino. 13 de septiembre de 1938.

García P., Rigoberto. “¿Quién es Jinarajadasa?” Cronos. 12 de octubre de 1938.

Hernández Martínez, Maximiliano. "La imperfección del ser humano". Archivo General de la Nación. Sección: familiares y personales, fondo: MHM, serie: 05, pláticas doctrinales, caja 2. Exp. 52, folio 1, $1^{\circ}$ de diciembre de 1942.

Jinarajadasa, Carlos. "Que es la teosofía”. Diario Nuevo. 26 de octubre de 1938.

Jinarajadasa, Carlos. “QQué es la teosofía?” Diario Oficial, Suplemento La República. 25 de agosto de 1942.

La Época. "Mañana llegará a Tegucigalpa el filósofo C. Jinarajadasa". 15 de octubre de 1938.

La Prensa. "De las enseñanzas del Dr. C. Jinarajadasa". 24 de octubre de 1938.

Moncada, Salvador. "Vendrá el Dr. Jinarajadasa". El Cronista. 25 de agosto de 1938.

Museo de la Palabra y la Imagen. Espectroscopio, una columna de Salarrué: acotaciones, comentarios y especulaciones en La Metafisica. Sin fecha, bajo clasificación: SVMUP1-I (1.2-F20.1).

Narváez G., Emilio. "El Doctor Jinarajadasa: breve semblanza de su personalidad”. Diario Nuevo. 20 de septiembre de 1938.

Novedades. "Pronto llegará el filósofo Jinarajadasa". 21 de septiembre de 1938.

Oliva N. G. "Éxtasis e introspección". Diario de Oriente. 23 de marzo de 1938.

Roger, Remy. "Concepto errado que de la teosofía tienen algunos". El Cronista. 31 de octubre de 1938.

Tavel, A. G. "Teosofía". El Cronista. 15 de octubre de 1938.

Urbina, Luis A. "El espiritismo". Diario Nuevo. 3 de agosto, 1938.

\section{Bibliografía}

Abellán, José Luis. Historia crítica del pensamiento español: la crisis contemporánea, 1875-1936, Tomo VII. Madrid: Editorial Espasa-Calpe S.A., 1988.

Ayllón, José Ramón. En torno al hombre: introducción a la filosofía. Madrid: Ediciones Rialp, 2001. 
Calle, Ramiro. Historia de las Sociedades Secretas: el enigmático origen de templarios, masones, rosacruces y otras sectas ocultas. Málaga: Editorial Sirio S.A., 2010.

Caniff, Patricia. Pitágoras, grandes iniciado. Madrid: Ediciones y distribuciones Mateos, 1998.

Canterla González, Cinta. "Neoplatonismo, filosofía natural y misticismo fuentes ocultas del romanticismo en el Kant precrítico". Cuadernos de Ilustración y romanticismo 1 (1991): 13-173.

Caro, José María. ¿Qué es la teosofía? Santiago de Chile: Difusión chilena, 1942.

Casus Arzú, Marta Elena. "El vitalismo teosófico como discurso alternativo de las élites intelectuales centroamericanas en la década de 1920 y 1930. Principales difusores: Alberto Masferrer, Carlos Wild Ospina y Porfirio Barba Jacob”. REHMLAC 3, no. 1 (mayo-noviembre 2011):

$82-120$ https://revistas.ucr.ac.cr/index.php/rehmlac/article/view/6588/6279

Cortijo Parralejo, Esteban. "Vida y obra de Mario Roso de Luna, 1872-1931, abogado, científico y escritor". Tesis de doctorado en filosofía, Universidad Complutense de Madrid, 1991.

Feuerbach, Ludwig. La esencia del cristianismo. Buenos Aires: Editorial Claridad, S.A, 2006.

Francois Lyotard, Jean. "Qué es lo posmoderno". Zona Erógena 12 (1992): 2-10.

González, Horacio. Historia crítica de la sociología argentina: los raros, los clásicos, los cientificos, los discrepantes. Buenos Aires: ediciones Colihue, S.R.L, 2000.

Gutiérrez Rueda, Carlos. "El escepticismo filosófico antiguo y el problema de la justificación epistémica". Revista Elementos: ciencia y cultura 10, no. 51 (2010): 43-51.

Hume, David. Sobre el suicidio y otros ensayos. Madrid, España: Alianza Editorial, 1988.

Hume, David. Tratado de la naturaleza humana, tomo I. México: Ediciones Gernika S.A., 1992.

Hutin, Serge. Las sociedades secretas. Madrid: Biblioteca de Ensayo Siruela, Ediciones Siruelas S.A., 2008.

Ingenieros, José. Las direcciones filosóficas de la cultura argentina. Buenos Aires: Eudeba editorial Universitaria, 1963.

López Anadón, Pedro. Krishnamurti, vida y obra. Madrid: Editorial Oberon, Grupo Anaya, S.A., 2003.

López Martín, Dolores. "El espiritismo, la parasicología y el cuento fantástico hispanoamericano del siglo XIX". Revista Arrabal 5-6 (2007): 39-46.

Miret Magdalena, Enrique. Occidente mira a Oriente: su mensaje de sabiduría y desarrollo humano. Barcelona: Plaza y Janés Editores S.A., 1999.

Mora-Burgos, Gerardo. La filosofía en la América Central en el siglo XX. Madrid: Editorial Cátedra, 2009.

Orio de Miguel, Bernardino. "El principio de analogía en Leibniz". Revista Enrahonar 14 (1988): 33-61.

Pomés Vives, Jordi. "Dialogo Oriente-Occidente en la España de finales del siglo XIX. El primer teosofismo español (1888-1906) un movimiento religioso heterodoxo bien integrado en los movimientos sociales de la época". Orientats 4 (2006): 55-74. 
Quereilhac, Soledad. “Sociedades espiritualistas en el pasaje de siglos: entre el cenáculo y las promesas de una ciencia futura, (1880-1910)". Revista de historia intelectual: Prismas 16 (2012): 183-186.

Reale, Giovanni y Dario Antíseri. Historia de la filosofía, tomo I: filosofía pagana antigua. Bogotá: Editorial San Pablo, 2007.

Rodríguez-Dobles, Esteban. "Redes esotéricas en Centroamérica y Colombia (1904-1940). El caso de la sociedad teosófica". Melancolía 1 (2016): 75-106. http://revistamelancolia.com/index.php/melancolia/article/view/5/5

Russell, Bertrand. Por qué no soy cristiano. Barcelona: Editora Hispanoamérica S.A., 1979. Urbina Gaitán, Chester. "Iglesia, Estado y control mental en Costa Rica: el caso de la prohibición de la enseñanza de la teosofía en el Colegio Superior de Señoritas, 1922". Revista de Ciencias Sociales 150 (2015): 53-61.

Vasconcelos Caldrerón, José. Estética. Antología de Gerardo González Macgregor. México DF: Ediciones Oasis S.A.

Vivekananda, Swami. Conferencias Teosóficas. Barcelona: Antonio Roch Editor, sfp.

Zambrano, María. Hacia un saber sobre el alma. Madrid: Alianza Editorial S.A., Fundación María Zambrano, 2001.

Zubiri, Xavier. Naturaleza, historia y Dios. Madrid: Alianza Editorial S.A., Fundación Xavier Zubiri, 2004. 